\title{
TCF7L2 rs7903146 polymorphism association with diabetes and obesity in an elderly cohort from Brazil
}

\author{
Lais Bride ${ }^{1}$, Michel Naslavsky ${ }^{2}$, Guilherme Lopes Yamamoto ${ }^{2}$, Marilia Scliar ${ }^{2}$, Lucia HS Pimassoni ${ }^{3}$, Paola Sossai \\ Aguiar $^{1}$, Flavia Paula ${ }^{1,4}$, Jaqueline Wang ${ }^{2}$, Yeda Duarte ${ }^{5,6}$, Maria Rita Passos-Bueno ${ }^{2}$, Mayana Zatz ${ }^{2}$, Flávia \\ Imbroisi Valle Errera ${ }^{\text {Corresp. } 1,4}$ \\ ${ }^{1}$ Biotechnology Graduate Program, Federal University of Espírito Santo, Vitória, Espírito Santo, Brazil \\ 2 Biosciences Institute, University of São Paulo, São Paulo, São Paulo, Brazil \\ 3 School of Science of Santa Casa de Misericórdia de Vitória, Vitória, Espírito Santo, Brazil \\ 4 Department of Biological Sciences, Federal University of Espírito Santo, Vitória, Espírito Santo, Brazil \\ 5 School of Nursing, University of São Paulo, São Paulo, São Paulo, Brazil \\ ${ }^{6}$ School of Public Health, University of São Paulo, São Paulo, São Paulo, Brazil \\ Corresponding Author: Flávia Imbroisi Valle Errera \\ Email address: flavia.valle@ufes.br
}

Background. Type 2 diabetes mellitus (T2DM) and obesity are complex pandemic diseases in the 21st century. Worldwide, the T allele rs7903146 in the TCF7L2 gene is recognized as a strong GWAS signal associated with T2DM. However, the association between the $\mathrm{C}$ allele and obesity is still poorly explored and needs to be replicated in other populations. Thus, the primary objectives of this study were to evaluate the TCF7L2 rs7903146 association with T2DM according to BMI status and to determine if this variant is related to obesity and BMI variation in a cohort of elderly Brazilians.

Methods. A total of 1,023 participants from an elderly census-based cohort called SABE (Saúde, Bem Estar e Envelhecimento - Health, Well-Being and Aging) were stratified by BMI status and type 2 diabetes presence. The TCF7L2 genotypes were filtered from the Online Archive of Brazilian Mutations (ABraOM Online Archive of Brazilian Mutations) database, a web-based public database with sequencing data of samples of the SABE's participants. Logistic regression models and interaction analyses were performed. The BMI variation ( $\triangle \mathrm{BMI}$ ) was calculated from anthropometric data collected in up to two time-points with a ten-year-assessment interval.

Results. The association between the rs7903146 T allele and T2DM was inversely proportional to the BMI status, with an increased risk in the normal weight group (OR 3.36; 95\% Cl 1.46-7.74; $P=0.004$ ). We confirmed the T allele association with risk for T2DM after adjusting for possible confound ing variables (OR 2.35; $95 \% \mathrm{Cl} 1.28-4.32 ; P=0.006$ ). Interaction analysis showed that the increased risk for T2DM conferred by the T allele is modified by BMI $\left(P_{\text {interaction }}=0.008\right)$, age $\left(P_{\text {interaction }}=0.005\right)$ and gender $\left(P_{\text {interaction }}=0.026\right)$. A T allele protective effect against obesity was observed (OR $0.71 ; 95 \% \mathrm{Cl} 0.54-0.94$; $P=0.016)$. The $C$ allele increased obesity risk (OR $1.40 ; 95 \% \mathrm{Cl} 1.06-1.84 ; P=0.017$ ) and the CC genotype showed a borderline association with abdominal obesity risk (OR $1.28 ; 95 \% \mathrm{Cl} 1.06-1.67 ; P=0.045)$. The CC genotype increased the obesity risk factor after adjusting for possible confounding variables (OR 1.41; $95 \% \mathrm{Cl} 1.06-1.86 ; P=0.017)$. An increase of the $\Pi$ genotype in the second tertile of $\Delta \mathrm{BMI}$ values was observed in participants without type 2 diabetes (OR 5.13; 95\% Cl 1.40-18.93; $P=0.009$ ) in the recessive genetic model. Conclusion. We confirmed that the rs7903146 is both associated with T2DM and obesity. The TCF7L2 rs7903146 T allele increased T2DM risk in the normal weight group and interacted with sex, age and $\mathrm{BMI}$, while the $\mathrm{C}$ allele increased obesity risk. The $\Pi \mathrm{T}$ genotype was associated with a lesser

Peer) reviewing PDF | (2020:10:53366:2:0:NEW 25 Mar 2021) 
extent of BMI variation over the SABE study's ten-year period. 
1 TCF7L2 rs7903146 polymorphism association with 2 diabetes and obesity in an elderly cohort from Brazil

3

4

5 Lais de Lima Bride ${ }^{1}$, Michel Satya Naslavsky², Guilherme Lopes Yamamoto², Marilia Oliveira

6 Scliar $^{2}$, Lúcia Helena Sagrillo Pimassoni ${ }^{3}$, Paola Sossai Aguiar ${ }^{1}$, Flávia de Paula ${ }^{1,4}$, Jaqueline Yu

7 Ting Wang ${ }^{2}$, Yeda Aparecida Oliveira Duarte ${ }^{5,6}$, Maria Rita Passos-Bueno ${ }^{2}$, Mayana Zatz ${ }^{2}$,

8 Flávia Imbroisi Valle Errera ${ }^{1,4}$

9

10

${ }^{1}$ Biotechnology Graduate Program, Federal University of Espírito Santo, Vitória, Espírito Santo, Brazil

${ }^{2}$ Human Genome and Stem Cell Research Center, Biosciences Institute, University of São Paulo, São Paulo, Brazil

${ }^{3}$ School of Science of Santa Casa de Misericórdia de Vitória, Vitória, Brazil

${ }^{4}$ Center for Human and Molecular Genetics, Department of Biological Sciences, Center for Human and Natural Sciences, Federal University of Espírito Santo, Vitória, Espírito Santo, Brazil

${ }^{5}$ School of Nursing, University of São Paulo, São Paulo, Brazil

${ }^{6}$ School of Public Health, University of São Paulo, São Paulo, Brazil

Corresponding Author:

Flávia Imbroisi Valle Errera ${ }^{1,4}$

Avenida Fernando Ferrari, 514, Edifício Lydia Behar, sala 105, Vitória, Espírito Santo, zip code 29075-910, Brazil.

Email address: flavia.errera@gmail.com, flavia.valle@ufes.br 
39

40

41

42

43

44

45

46

47

48

49

50

51

52

53

54

55

56

57

58

59

60

61

62

63

64

65

66

67

68

69

70

71

72

73

74

75

76

77

78

\section{Abstract}

Background. Type 2 diabetes mellitus (T2DM) and obesity are complex pandemic diseases in the 21 st century. Worldwide, the T allele rs7903146 in the TCF7L2 gene is recognized as a strong GWAS signal associated with T2DM. However, the association between the C allele and obesity is still poorly explored and needs to be replicated in other populations. Thus, the primary objectives of this study were to evaluate the TCF7L2 rs7903146 association with T2DM according to BMI status and to determine if this variant is related to obesity and BMI variation in a cohort of elderly Brazilians.

Methods. A total of 1,023 participants from an elderly census-based cohort called SABE (Saúde, Bem Estar e Envelhecimento - Health, Well-Being and Aging) were stratified by BMI status and type 2 diabetes presence. The TCF7L2 genotypes were filtered from the Online Archive of Brazilian Mutations (ABraOM - Online Archive of Brazilian Mutations) database, a web-based public database with sequencing data of samples of the SABE's participants. Logistic regression models and interaction analyses were performed. The BMI variation ( $\triangle \mathrm{BMI}$ ) was calculated from anthropometric data collected in up to two time-points with a ten-year-assessment interval.

Results. The association between the rs7903146 T allele and T2DM was inversely proportional to the BMI status, with an increased risk in the normal weight group (OR 3.36; 95\% CI 1.467.74; $P=0.004)$. We confirmed the T allele association with risk for T2DM after adjusting for possible confounding variables (OR 2.35; 95\% CI 1.28 - 4.32; $P=0.006)$. Interaction analysis showed that the increased risk for T2DM conferred by the T allele is modified by BMI $\left(P_{\text {interaction }}=0.008\right)$, age $\left(P_{\text {interaction }}=0.005\right)$ and gender $\left(P_{\text {interaction }}=0.026\right)$. A T allele protective effect against obesity was observed (OR $0.71 ; 95 \%$ CI $0.54-0.94 ; P=0.016$ ). The $\mathrm{C}$ allele increased obesity risk (OR 1.40; 95\% CI 1.06-1.84; $P=0.017$ ) and the CC genotype showed a borderline association with abdominal obesity risk (OR 1.28; 95\% CI 1.06-1.67; $P=0.045)$. The $\mathrm{CC}$ genotype increased the obesity risk factor after adjusting for possible confounding variables (OR $1.41 ; 95 \%$ CI $1.06-1.86 ; P=0.017$ ). An increase of the TT genotype in the second tertile of $\triangle \mathrm{BMI}$ values was observed in participants without type 2 diabetes (OR 5.13; 95\% CI 1.40-18.93; $P=0.009)$ in the recessive genetic model.

Conclusion. We confirmed that the rs7903146 is both associated with T2DM and obesity. The TCF7L2 rs7903146 T allele increased T2DM risk in the normal weight group and interacted with sex, age and BMI, while the $\mathrm{C}$ allele increased obesity risk. The TT genotype was associated with a lesser extent of BMI variation over the SABE study's ten-year period. 


\section{Introduction}

80 Type 2 diabetes mellitus (T2DM) and obesity are considered pandemic diseases. They are 81 interconnected by insulin mechanisms and characterized by complex interactions between 82 environmental and genetic factors (Haupt et al., 2010; Chen et al., 2018; Grant, 2019). In this 83 context, crucial T2DM genes involved in insulin production, processing, trafficking and secretion 84 can also play a significant role in obesity development (Noordam et al., 2017; Fernández-Rhodes 85 et al., 2018). The TCF7L2 (10q25.2), one of these genes, encodes a transcription factor member 86 of the Wnt signaling pathway known to act on vital functions of $\beta$ cells and glucose metabolizing 87 tissues (Cropano et al., 2017).

88

89

90

91

92

93

94

95

96

97

98

99

100

101

102

103

104

105

106

107

108

109

110

111

112

113

114

115

116

117

\section{2}

The rs7903146 T allele in TCF7L2 is the strongest GWAS signal for T2DM risk in different populations across the world and it is associated with insulin synthesis, processing, secretion and action mechanisms (Grant et al., 2006; Cauchi et al., 2008b; Bouhaha et al., 2010; Zhou et al., 2014; Corella et al., 2016; Cropano et al., 2017). The genetic susceptibility for T2DM is modulated by BMI, suggesting a potential relationship between the rs 7903146 variant and risk for obesity. Such factors may be related to the TCF7L2 expression and the Wnt pathway regulation of adipose tissue (Ross et al., 2000; Grant et al., 2006; Zhou et al., 2014; Cropano et al., 2017; Chen et al., 2018).

The Wnt signaling pathways negatively regulate adipogenesis and play important metabolic and developmental roles in adipose tissue composition and functioning (Chen \& Wang, 2018). Although the TCF7L2 encodes the main effector involved in this signaling pathway, few studies investigate the association between the rs7903146 and risk for obesity (Haupt et al., 2010; A1Daghri et al., 2014; Locke et al., 2015; Abadi et al., 2017; Muller et al., 2019). These studies reported an association between the rs7903146 C allele and the risk for obesity. In this sense, validation research for the association in other populations is compelling (Grant, 2019).

We hypothesize that the rs7903146 variant is associated not only with T2DM but also with obesity. We aimed to explore the relation between T2DM risk conferred by the rs7903146 SNP and BMI status, verifying differences among the rs7903146 genotypes on BMI variation over a ten-year period. Furthermore, we performed interaction analyses of this genetic variant with BMI, age and gender. 


\section{Materials \& Methods}

\section{Study Cohort}

120 We recruited elderly volunteers from a health survey called SABE (Saúde, Bem Estar e

121 Envelhecimento - Health, Well-Being and Aging). SABE was carried out in São Paulo, Brazil,

122 under the coordination of the Pan American Health Organization. The project was initially a

123 multicenter health survey and well-being of older people in seven Caribbean and Latin American

124 urban centers (Bridgetown, Barbados; Buenos Aires, Argentina; Havana, Cuba; Mexico City,

125 Mexico; Montevideo, Uruguay; Santiago, Chile; and São Paulo, Brazil). The Brazilian center has

126 since adopted a longitudinal approach with a new data collection every five years, under the

127 coordination of the Public Health School at the University of São Paulo (Lebrão \& Laurenti,

128 2005).

129

130

SABE was approved by the Ethics in Research Committee of the School of Public Health of the

131

132 University of São Paulo and the Brazilian National Committee for Ethics in Research under

133 protocol number 2015/12837/1.015.223. All participants signed an informed consent form under the Brazilian regulatory requirements of research with human subjects. A detailed description of the study population, including demographic characteristics, clinical and anthropometric data, medical history and socioeconomic background, has been previously published (Lebrão \& Laurenti, 2005).

In addition, SABE was approved by the Institutional Review Board of the University of São Paulo School of Public Health (CAAE: 47683115.4.0000.5421, Review: 3.600.782). All genomic dataset subjects have agreed to participate in this study and signed the written informed consent form approved by CEP/CONEP (Brazilian local and national Ethical Committee Boards).

\section{Clinical and Anthropometric Characteristics}

Data was collected by a specific standardized questionnaire (C10) proposed by the Pan American Health Organization (PAHO), which was translated and adapted for use in Brazil (Naslavsky et al., 2017). Trained interviewers administered the questionnaire in subjects' households. The T2DM was considered self-reported if the subject provided an affirmative answer to the question, "Have you ever been told by a doctor or other health professional that you have diabetes or high blood sugar levels?". Blood was withdrawn and submitted to biochemical and

152

153 We assessed the following demographic and health variables: gender, age, fasting plasma glucose $(\mathrm{mg} / \mathrm{dL})$, glycated hemoglobin $(\%)$, total cholesterol $(\mathrm{mg} / \mathrm{dL})$, fasting triglyceride (mg / $\mathrm{dL})$, LDL cholesterol ( $\mathrm{mg} / \mathrm{dL})$, HDL cholesterol $(\mathrm{mg} / \mathrm{dL})$, systolic pressure $(\mathrm{mmHg})$, diastolic pressure $(\mathrm{mmHg})$, BMI $\left(\mathrm{kg} / \mathrm{m}^{2}\right)$, waist circumference $(\mathrm{cm})$, hip circumference $(\mathrm{cm})$, and hipwaist ratio $(\mathrm{cm} / \mathrm{cm})$. All participants with T2DM and/or with blood glucose levels above 100 
158

159

160

161

162

163

164

165

166

167

168

169

170

171

172

173

174

175

176

177

178

179

180

181

182

183

184

185

186

187

188

189

190

191

192

193

194

195

196

197

$\mathrm{mg} / \mathrm{dL}$ were considered hyperglycemic. For anthropometric evaluation, the weight was measured using a portable scale (Seca, Germany), and the height was measured using an anthropometer (Harpenden, England). Waist circumference was measured using an inelastic measurement tape placed on the midpoint between the lower margin of the last palpable riband and the top of the iliac crest. Hip circumference was measured around the widest portion of the buttocks.

The BMI was calculated from weight and height at baseline from the ratio of body weight (in kilograms) to height in square meters. We stratified individuals into three groups according to the World Health Organization (WHO) criteria for BMI classification: normal weight (18.5 $24.9 \mathrm{~kg} / \mathrm{m} 2)$, overweight $(25.0-29.9 \mathrm{~kg} / \mathrm{m} 2)$ and obesity $(\geq 30.0 \mathrm{~kg} / \mathrm{m} 2)$. Abdominal obesity was defined by the waist circumference $>88 \mathrm{~cm}$ for women and $>102 \mathrm{~cm}$ for men.

Anthropometric data were analyzed twice over ten years (2000 and 2010). The BMI variation ( $\triangle \mathrm{BMI}$ ) of each elderly was obtained from the difference between the BMI measured in the collection years 2010 and 2000.

After excluding subjects with incomplete data, this study was carried out in a multiethnic population of 1,023 elderly individuals. The cohort included men and women whose anthropometric, biochemical, and genetic information were evaluated to verify association with T2DM, obesity, and BMI variation over ten years.

\section{Next-Generation Sequencing Data}

We selected the TCF7L2 rs7903146 SNP because of its high predictive power (effect size $\times$ allele frequency) in the Latin American population. It is also localized in a gene related to various cellular processes involved in T2DM development (Berumen et al., 2019). We filtered the TCF7L2 rs7903146 genotypes from the whole-genome sequencing dataset of SABE, the second phase of genomic analyses following the dataset deposited in ABraOM - Arquivo Brasileiro Online de Mutações (Online Archive of Brazilian Mutations, http://abraom.ib.usp.br). Quality control of genotypes and variants is described by Naslavsky et al. (2017) and by Naslavsky et al. (2020).

\section{Statistical Analysis}

Data regarding continuous variables were expressed as percentages and the mean \pm standard deviation (SD) and percentages for categorical variables. The one-sample Kolmogorov-Smirnov test was used to test the normality. Differences between groups for categorical data were tested by $\chi^{2}$ analysis, while Independent Samples Mann-Whitney U test and the Kruskal-Wallis test were used for continuous data. Allele frequencies were determined by gene counting and HardyWeinberg equilibrium deviations were verified using a $\chi^{2}$ test.

Allele and genotype distributions among groups were evaluated with $\chi^{2}$ test or Fisher's exact test. The level of significance adopted was $P<0.05$. Logistic regression models were developed 
198

199

200

201

202

203

204

205

206

207

208

209

210

211

212

213

214

215

216

217

218

219

220

221

222

223

224

225

226

227

228

229

230

231

232

233

234

235

236

237

after adjusting for age and gender and were performed to assess the independent role of the TCF7L2 genotype. Interaction analysis was performed. The rs7903146 genotypic frequencies were compared among the $\triangle B M I$ tertiles. SPSS (version 25.0.0.0) software was used for general statistics.

A power analysis was performed using the software $G^{*}$ Power version 3.1.9.2 to verify the rs790314 association with T2DM and obesity. The sample size was 1,023, and to perform the power analysis were considered: a significance level of 0.05 , the OR of 1.3 , a statistical power of $90 \%$, the expected squared coefficient of multiple correlations $\left(\mathrm{R}^{2}\right)$ of 0.25 (moderate association).

\section{Results}

The main clinical features of the 1,023 participants are depicted in Table 1 . The median age of participants was 71.4 years old (59-99 years old), and $64.32 \%$ of participants were women. The three groups clustered by BMI status contain 280 subjects with normal weight, 424 with overweight and 319 with obesity (Table 1). These groups did not differ in systolic pressure, total cholesterol and LDL cholesterol. However, groups differed in gender ratio, age, waist circumference, hip circumference, hip-waist ratio, diastolic pressure, plasma glucose, glycated hemoglobin, fasting triglyceride, HDL cholesterol and number of subjects with T2DM and arterial hypertension (Table1).

The genotypic distributions for the rs7903146 were in Hardy-Weinberg equilibrium in all groups (All $P>0.05$ ). These genotypic and allelic distributions of participants with and without T2DM according to BMI status are shown in Supplemental Table 1 (All $P>0.05$ ). In addition, the analysis of ancestries frequency is demonstrated in Supplemental Table 2. There was a significant difference in European contribution among the genotypes $(P=0.007)$ and between Non-T2DM and T2DM groups $(P=0.020)$.

The TT genotype was more frequent in the T2DM group $(P=0.0001)$. The TCF7L2 rs7903146 T allele, in association with T2DM, was confirmed on the recessive genetic model (OR=1.89; $95 \%$ CI: $1.21-2.95 ; P=0.004)$, but no significant associations were detected with other phenotypes (Supplemental Table 3). Significant association signals were detected between hyperglycemia and the $\mathrm{T}$ allele on the dominant genetic model $(\mathrm{OR}=1.77 ; 95 \% \mathrm{CI}: 2.61-1.20 ; P=0.004)$ as well as on the log-additive model (OR=1.56; 95\% CI: $2.09-1.17 ; P=0.002)$ (Supplemental Table 4). Yet, a $\mathrm{C}$ allele protective effect was also observed against $\mathrm{T} 2 \mathrm{DM}$ under dominant (OR=0.51; 95\% CI:0.32 - 0.80; $P=0.003)$, additive (OR=0.50; 95\% CI:0.31 $-0.81 ; P=0.004)$ and allelic $(\mathrm{OR}=$ 0.79; 95\% CI: $0.64-0.98 ; P=0.031$ ) genetic models (Supplemental Table 5).

Peer] reviewing PDF | (2020:10:53366:2:0:NEW 25 Mar 2021) 
238 The regression analysis showed a risk for T2DM on TT carriers even after adjusting for all 239 confounds depicted in Table 1 (Table 2). However, the interaction analysis demonstrated that

240

241

242

243

244

245

246

247

248

249

250

251

252

253

254

255

256

257

258

259

260

261

262

263

264

265

266

267

268

269

270

271

272

273

274

275

276

277

278 BMI modifies the association between TT genotype and T2DM risk (OR=1.02; 95\% CI: 1.01 1.04; $P_{\text {interaction }}=0.008$ ). This result reinforces the logistic regression analysis stratified by BMI status, which showed that the risk for T2DM conferred by $\mathrm{T}$ allele is higher in the normal weight group, with the following odds ratios: $(\mathrm{OR}=3.36$; $95 \% \mathrm{CI}$ : $1.46-7.74 ; P=0.004)$ for the recessive model and (OR=3.21; 95\% CI: $1.31-7.87 ; P=0.011)$ for the additive model (Table 3$)$. In addition, the $\mathrm{T}$ allele and age interaction analysis demonstrated that the increased T2DM risk in TT carries is maintained, and the age affects this association (OR=1.01; $95 \% \mathrm{CI}: 1.00-1.02$; $P_{\text {interaction }}=0.005$ ).

Association tests separated by gender showed a borderline association between the TT genotype and risk for T2DM in men ( $\mathrm{OR}=2.19 ; 95 \% \mathrm{CI}: 1.05-4.58 ; P=0.042)$. Tests also reported a trend for association in women $(\mathrm{OR}=1.75 ; 95 \% \mathrm{CI}: 1.00-3.07 ; P=0.055)$. After grouping subjects from the normal weight and overweight groups and excluding the obese group, we observed association both in men $(\mathrm{OR}=2.64 ; 95 \% \mathrm{CI}: 1.16-5.98 ; P=0.020)$ and women $(\mathrm{OR}=2.14 ; 95 \% \mathrm{CI}: 1.08-$ 4.21; $P=0.028)$. However, in the normal weight group, we noticed a strong association in men $(\mathrm{OR}=5.48 ; 95 \% \mathrm{CI}: 1.57-19.10 ; P=0.008)$ while there was no association in women. Furthermore, this result is also reinforced by the interaction analysis of the TT genotype and gender on the risk for T2DM $\left(\mathrm{OR}=1.87 ; 95 \% \mathrm{CI}: 1.08-3.25 ; P_{\text {interaction }}=0.026\right)$.

The association between the rs7903146 variant and obesity status was analyzed and the T allele conferred protection against obesity on the dominant model (OR=0.71; 95\% CI: 0.54-0.94; $P=0.016$ ) (Supplemental Table 6). This result leads us to believe that there is an association between the $\mathrm{C}$ allele and obesity. Our analysis revealed a $\mathrm{CC}$ genotype association with obesity risk on the recessive model (OR 1.40; 95\% CI 1.06-1.84; $P=0.017$ ) (Table 4). The regression analysis showed a higher risk for obesity on $\mathrm{CC}$ carriers even after adjustment for all the possible confounds (OR 1.41; 95\% CI $1.06-1.86 ; P=0.017$ ) (Table 5). Additionally, we observed a borderline association with abdominal obesity in subjects with $\mathrm{CC}$ genotype $(\mathrm{OR}=1.29 ; 95 \% \mathrm{CI}$ : $1.28-1.67 ; P=0.045)$.

Analysis of BMI variation over ten years of SABE study revealed a different distribution of rs7903146 genotypes among $\triangle B M I$ tertiles (Supplemental Tables 7 and 8). We observed an increase in the TT genotype in the $\triangle \mathrm{BMI}$ second tertile compared to the first tertile. The increased frequency in the TT genotype was detected on the recessive genetic model (OR 2.00; 95\% CI $1.01-3.97 ; P=0.044$ ) and in participants without T2DM, both on the additive (OR 5.13; $95 \%$ CI 1.40-18.93; $P=0.009$ ) as on the recessive model (OR 5.13; 95\% CI 1.43-18.37; $P=$ 0.010) (Supplemental Table 7). No significant values were found among individuals with T2DM (Supplemental Table 8). 


\section{Discussion}

280 We evaluated the TCF7L2 rs7903146 association with T2DM and obesity. We explored whether

281

282

283

284

285

286

287

288

289

290

291

292

293

294

295

296

297

298

299

300

301

302

303

304

305

306

307

308

309

310

311

312

313

314

315

316

317

318

the strength of association with T2DM depends on BMI status (normal-weight, overweight and obesity). The differences in BMI variation over ten years on $\mathrm{C}$ and $\mathrm{T}$ allele carriers were also investigated. We confirmed that the T allele risk confers risk for T2DM, and it is influenced by BMI status, age and gender. The TT genotype conferred a protective effect against obesity and the CC genotype was associated with risk for obesity. Moreover, the TT genotype was associated with a lower BMI variation over a ten-year period in our elderly cohort.

According to the Allele Frequency Aggregator (ALFA) project from the National Center for Biotechnology Information (NCBI) database, the worldwide frequency for the rs $7903146 \mathrm{~T}$ allele is around 0.29 (Phan et al., 2020). In our population, T allele frequency varied from 0.27 to 0.33 among the categories, except for the normal weight diabetic elderly group. For this group, the $\mathrm{T}$ allele frequency was around 0.40 (Supplemental Table 1). Thereafter, we performed regression analysis adjusted for gender and age, which confirmed the rs7903146 T allele risk for T2DM in the total population (Table 3).

Other Brazilian studies also reported the rs7903146 T allele association with risk for T2DM (Barra et al., 2012; Assmann et al., 2017). However, these studies did not investigate the influence of BMI on diabetes risk or addressed this issue considering an elderly population. Thus, we verified an increased risk for T2DM conferred by the rs7903146 T allele in lower BMI participants. This risk was higher in the normal weight group (OR 3.36; 95\% CI 1.46-7.74; $P=0.004$ ) (Table 3). Previous studies, with populations from other countries, also reported a higher risk for T2DM when the BMI is lower (Cauchi et al., 2006, 2008b; Bouhaha et al., 2010; Corella et al., 2016). Cauchi et al., (2008) and Corella et al., (2016) observed odds ratios of 1.89 (95\% CI: 1.67-2.14) and 2.32 (95\% CI: 1.90-2.85) in individuals without obesity, respectively. Meanwhile, Bouhaha et al. (2010) reported an odds ratio (OR 3.24; 95\% CI: 1.10-9.53) similar to our results. Perry et al. (2012), when analyzing 36 diabetes loci, verified, in 29 of them, a higher risk for T2DM in normal weight individuals compared to obese individuals.

The rs7903146 T allele may have a more significant impact on individuals without obesity. This impact is due not to the obesity-induced insulin resistance but due to pancreatic dysfunction, indicating that $\beta$-cell impairment predicts a future T2DM in subjects with lower BMI (Cauchi et al., 2008b; Bouhaha et al., 2010). Among leaner subjects, the $\beta$-cell compensation is lower, while among people with obesity, the compensation is higher (Watanabe et al., 2007). Plasmids carrying the $\mathrm{T}$ allele showed more robust transcriptional activity when compared to those with the $\mathrm{C}$ allele. In addition, pancreatic cells with $\mathrm{T}$ allele carriers showed impaired proinsulin processing, resulting in a high level of proinsulin in the plasma and an increased proinsulin/insulin ratio (Stolerman et al., 2009). Human islets have a higher degree of open chromatin, corroborating that the $\mathrm{T}$ allele leads to an increased expression of TCF7L2 and

Peer) reviewing PDF | (2020:10:53366:2:0:NEW 25 Mar 2021) 
319 decreased insulin content and secretion (Zhou et al., 2014). Additionally, Zhou et al. (2014)

320

321

322

323

324

325

326

327

328

329

330

331

332

333

334

335

336

337

338

339

340

341

342

343

344

345

346

347

348

349

350

351

352

353

354

355

356

357

358

demonstrated that in islets from CC genotype carriers, TCF7L2 mRNA expression was negatively associated with the genes ISL1, MAFA and NKX6.1 but not with MAFA and NKX6.1 in CT/TT genotype carriers. This finding reinforces the $\beta$-cell impairment in $\mathrm{T}$ allele risk carriers.

The difference in the association of genes between men and women has been previously explored. Interestingly, there is evidence that the TCF $7 L 2$ gene behaves differently in women and men. Moreover, He, Zhong and Cui (2014) conducted an integrated approach and observed gender differences in association signals at the gene-level and pathway-level. In this study, the $T C F 7 L 2$ association was found only in male subjects, and all SNPs in this gene, considering the female population, did not show significance. Since TCF7L2 belongs to several enriched pathways and is widely recognized as a gene conferring risk of T2DM, the authors performed the same analysis but deleting this gene in all pathways. They observed no significant change between pathway signals with and without the $T C F 7 L 2$ gene in the female group, while the strong signals in the male group were almost nonexistent after deleting the gene. This evidence suggests a potential difference in T2DM etiology in the pathway-level for each gender group. The authors verified that the significance of the pathways in the male group is primarily dominated by the TCF7L2 gene (He, Zhong \& Cui, 2014).

Berumen et al. (2019) investigated the influence of several factors on T2DM variability in Mexico. The authors observed that the factors contributed more in men (33.2\%) than in women $(25 \%)$. In addition, genes played a substantially more important role in men than in women $(14.9 \%$ vs. $5.5 \%)$, while obesity and parental history played a similar role in both genders. Genes and parental history appeared to play a more significant role than obesity in T2DM. According to Berumen et al., the effect of $T C F 7 L 2$ on men is more significant when the disease is diagnosed at $\leq 45$ years of age than when it is diagnosed at an older age, especially for the homozygous risk allele ( $\mathrm{OR}=4.62$ and 2.59 , respectively). Thus, the previously mentioned studies could explain the interaction between the $\mathrm{T}$ allele and gender on diabetes risk, which was observed in our study.

Our selected gene variant represents only a fraction of the studied gene's potential variation and the mechanisms involving TCF7L2, T2DM and obesity. Additional genetic studies with other variants are needed better to understand the $T C F 7 L 2$ role in these complex diseases. The rs 12255372 variant in intron 4 of the TCF7L2 gene showed strong linkage disequilibrium (LD) with rs7903146 (Pang, Smith \& Humphries, 2013). Moreover, subjects homozygous for the riskassociated allele showed higher gene expression in pancreatic islets and were more than twice as likely to develop T2DM as non-carriers (Lyssenko et al., 2007; Pang, Smith \& Humphries, 2013).

Peer) reviewing PDF | (2020:10:53366:2:0:NEW 25 Mar 2021) 
359

360

361

362

363

364

365

366

367

368

369

370

371

372

373

374

375

376

377

378

379

380

381

382

383

384

385

386

387

388

389

390

391

392

393

394

395

396

397

398

Prior association studies reported a lack of association between the rs7903146 T allele and obesity status (Cauchi et al., 2008b; Stolerman et al., 2009; Bouhaha et al., 2010; Al-Safar et al., 2015). However, we verified a $T$ allele protective effect against obesity (Supplemental Table 6), corroborating results reported in more recent studies (Noordam et al., 2017; Fernández-Rhodes et al., 2018). A cross-sectional analysis conducted in middle-aged participants (mean age of $55.9 \pm$ 6.0 years) reported a $\mathrm{T}$ allele association with lower BMI and mean total body fat (Noordam et al., 2017). Furthermore, Fernandez-Rhodes et al. (2018) showed an association between TT genotype, decreased waist circumference and lower mean BMI at multiple time points in the life course. This protection against obesity might be due to reduced insulin production and secretion related to the rs $7903146 \mathrm{~T}$ allele once insulin stimulates the increased glucose uptake in adipocytes. Insulin plays, therefore, a pro-obesogenic role both from its anabolic effect on lipid accumulation and due to compensatory eating to prevent episodes of hypoglycemia (Zhou et al., 2016).

Multiple factors are related to the changes in body composition with aging. From the fourth decade onwards, the muscle mass declines and accounts for reduced resting metabolic rates, which contribute to the gradual increase in body fat in elderly subjects (Gallagher et al., 1998; Sayer et al., 2008). Around 75 years of age, the BMI appears to be stable, yet it is overestimated due to an increase in fat mass and a decrease in lean mass and bone density (Ponti et al., 2020). In this sense, due to sarcopenic obesity, it is not easy to differentiate lean and obese elderlies. BMI cutoff points are still controversial for this range of age and, therefore, BMI classification is a limiting factor for our cohort. However, the BMI variation is a substantial risk predictor for elderlies and the rs $7903146 \mathrm{~T}$ allele protective effect against obesity deserves attention especially since thinness is a significant risk factor in old age, and weight loss is closely related to the frailty syndrome and other health complications (Aune et al., 2016; Di Angelantonio et al., 2016; Ponti et al., 2020).

Studies have reported clinical implications of sarcopenic obesity in subjects with T2DM (Khadra et al.; Ghoch, Calugi \& Grave, 2018; Kim \& Park, 2018). A recent meta-analysis observed that the presence of sarcopenic obesity increases the T2DM risk by $38 \%$ concerning those without sarcopenic obesity (OR $=1.38,95 \%$ CI: 1.27-1.50) (Khadra et al., 2019). The commonly accepted mechanism interconnecting T2DM and sarcopenic obesity involves an increase in fat mass, decrease in lean mass, chronic inflammation and insulin resistance; however, the mechanism itself is still unclear (Ponti et al., 2020). It can thus be said that the interaction between the $T$ allele and age on diabetes risk observed in our elderly cohort could be related to the sarcopenic obesity in older adults and the age-related decline in resting metabolic rates.

Our data further suggest a differential effect of rs7903146 genotypes in BMI variation only in elderly subjects without T2DM (Supplemental Table 7). Minor variation in BMI was observed among the TT genotype during the SABE ten-year period. This conclusion is drawn from the 
399

400

401

402

403

404

405

406

407

408

409

410

411

412

413

414

415

416

417

418

419

420

421

422

423

424

425

426

427

428

429

430

431

432

433

434

435

436

437

438

increased number of TT subjects without T2DM on the second tertile of $\Delta \mathrm{BMI}$ values (Supplemental Table 7). The same result is found in interventional studies that verified lower BMI variation in rs7903146 T allele carriers (Haupt et al., 2010; Kaminska et al., 2012; Roswall et al., 2014). Mattei et al., 2012 observed a greater loss of lean mass for CC subjects on a low-fat diet compared to TT (Mattei et al., 2012). Similarly, less weight gain per year was observed in patients with the $\mathrm{T}$ allele compared to the $\mathrm{C}$ allele after adopting a Mediterranean diet (Roswall et al., 2014). According to Fisher et al. (2012), the rs $7903146 \mathrm{C}$ allele arose during the transition from hunter-gatherer to agricultural practices, with a consequent reduction of protein sources). Carriers of the rs7906146 T allele were then selectively adapted to maintain weight stability under low-protein conditions (Fisher et al., 2012).

Helgason et al. (2007) reported that the rs7903146 T allele was the probable ancestral allele, serving for a better subjacent mutation. In addition, the authors identified a haplotype with the $\mathrm{C}$ allele (HapA). This haplotype indicates positive selection, besides the association with BMI and altered concentrations of ghrelin and leptin. It further indicates that the selective advantage of HapA may have been mediated through effects on energy metabolism (Helgason et al., 2007). Corroborating with these findings, the most significant GWAS meta-analysis for BMI so far ( $\sim 300,000$ subjects) reported a C allele association with BMI (Locke et al., 2015). Although the extent of clinical variability associated with the $\mathrm{C}$ allele is not fully known, significant associations between the rs7903146 C allele and BMI and/or waist circumference were observed in a Saudi population (Al-Daghri et al., 2014), in European adults (Abadi et al., 2017) and American Indians (Muller et al., 2019).

CC genotype subjects expressed more transcripts containing the alternative spliced exons (13 and $13 \mathrm{a})$ in their adipose tissue associated with BMI and body fat percentage than the T allele carriers (Kaminska et al., 2012). Furthermore, in addition to nine diabetes-associated genes, five in seven TCF7L2 splice forms were differentially expressed by comparing leukocyte cells of carriers of the $\mathrm{CC}$ and $\mathrm{CT} / \mathrm{TT}$ genotypes. This ratio might reflect a significant change in gene interactions and responsible networks as glucose homeostasis, adipogenesis and others (Vaquero et al., 2012). In this sense, the TCF7L2 alternative splicing in the adipose tissue could be regulated by health, disease, weight loss and insulin resistance (Mondal et al., 2010; Kaminska et al., 2012; Vaquero et al., 2012; Zhou et al., 2014; Chen et al., 2018).

The TCF7L2 gene plays important metabolic and developmental roles in adipose tissue composition and functioning. Therefore, it is largely hypothesized that the Wnt signaling is critical for obesity development (Chen \& Wang, 2018; Chen et al., 2018). This gene is differentially methylated in adipose tissue, exhibiting relevant epigenetic changes to the development of both diabetes and obesity (Nilsson et al., 2014). The TCF7L2 protein inactivation is associated with increased subcutaneous adipose tissue mass, adipocyte hypertrophy and inflammation (Chen et al., 2018). Furthermore, besides alternative splicing, other regulatory changes seem to be genotype- 
439 specific and further affect the TCF7L2 role in adipose tissue. Several protein factors, including 440 GATA3, a transcription factor that controls the preadipocyte-to-adipocyte transition, bind only to 441 the rs7903146 C allele but not to the $\mathrm{T}$ allele under caloric restriction (Cauchi et al., 2008a).

442

443

444

445

446

447

448

449

450

451

452

453

454

455

456

457

458

459

460

461

462

463

464

465

466

467

468

469

470

471

472

473

474

475

476

477

This evidence supports the CC genotype association with the risk of obesity and abdominal obesity in our population. Thus, we speculate that the inverse effects observed in our study of the rs7903146 T and C alleles on risks for diabetes and obesity. Such effects might be related to the TCF7L2 expression and its genotype-specific effects on the WNT signaling pathway in adipose tissue and others. We recognize the advances in knowledge regarding the production, processing, trafficking and secretion of insulin. However, more studies are required to understand further the mechanisms interconnecting the TCF7L2 rs7903146 variant, T2DM and obesity.

The main strength of this study is the median age of our population, which exceeds the-age of onset of diabetes and obesity, thus minimizing a typical bias in the selection of the control group. As far as we know, this is one of the few association studies that reported an association of the rs 7903146 variant with BMI variation during a 10-year-interval assessment. It is also unique to investigate obesity status in an exclusively elderly cohort. Dietary factors play an essential role in T2DM etiology and the gene-diet interaction could influence T2DM pathogenesis (OuhaibiDjellouli et al., 2014; Hindy et al., 2016). Therefore, the lack of assessment regarding dietary aspects as well as physical activity levels could be a limitation of our study. However, we could detect and confirm the association between T2DM and the rs7903146 $\mathrm{T}$ allele in our population, worldwide recognized as the strongest GWAS signal for diabetes risk (Grant, 2019). Despite our population size, we were able to reproduce significant results following more recent studies performed on larger populations (Locke et al., 2015; Abadi et al., 2017; Fernández-Rhodes et al., 2018).

\section{Conclusions}

We confirmed that the rs7903146 variant is associated with both T2DM and obesity. This result is supported by evolutive aspects and functional studies concerning the $\mathrm{T}$ and $\mathrm{C}$ alleles, contributing to knowledge expansion regarding this barely explored association. In addition, we found a TT association with a lower BMI variation in elderly subjects over the ten years of the SABE study. These findings provide a unique contribution to the field of association studies about this polymorphism. Nevertheless, additional studies are needed to understand the TCF7L2 rs7903146 association with obesity and with BMI variation in different age groups of populations across the world.

\section{Acknowledgments}

The authors acknowledge all volunteers and professionals who participated in the SABE survey. They would also like to thank the Academic Publishing Advisory Center (Centro de Assessoria 
478 de Publicação Acadêmica, CAPA, www.capa.ufpr.br) of the Federal University of Paraná

479 (UFPR) for assistance with English language editing.

480

481

482

483

484

485

486

487

488

489

490

491

492

493

494

495

496

497

498

499

500

501

502

503

504

505

506

507

508

509

510

511

512

513

514

515

516

517

518

519

520

521

522

\section{References}

Abadi A, Alyass A, Robiou du Pont S, Bolker B, Singh P, Mohan V, Diaz R, Engert JC, Yusuf S, Gerstein HC, Anand SS, Meyre D. 2017. Penetrance of Polygenic Obesity Susceptibility Loci across the Body Mass Index Distribution. American Journal of Human Genetics 101:925-938. DOI: 10.1016/j.ajhg.2017.10.007.

Al-Daghri NM, Alkharfy KM, Al-Attas OS, Krishnaswamy S, Mohammed AK, Albagha OM, Alenad AM, Chrousos GP, Alokail MS. 2014. Association between type 2 diabetes mellitus-related SNP variants and obesity traits in a Saudi population. Molecular Biology Reports 41:1731-1740. DOI: 10.1007/s11033-014-3022-z.

Al-Safar H, Hassoun A, Almazrouei S, Kamal W, Afandi B, Rais N. 2015. Association of the genetic polymorphisms in transcription factor 7-like 2 and peroxisome proliferator-activated receptors- $\gamma 2$ with type 2 diabetes mellitus and its interaction with obesity status in Emirati population. Journal of Diabetes Research 2015. DOI: 10.1155/2015/129695.

Di Angelantonio E, Bhupathiraju SN, Wormser D, Gao P, Kaptoge S, de Gonzalez AB, Cairns BJ, Huxley R, Jackson CL, Joshy G, Lewington S, Manson JAE, Murphy N, Patel A V., Samet JM, Woodward M, Zheng W, Zhou M, Bansal N, Barricarte A, Carter B, Cerhan JR, Collins R, Smith GD, Fang X, Franco OH, Green J, Halsey J, Hildebrand JS, Ji Jung K, Korda RJ, McLerran DF, Moore SC, O’Keeffe LM, Paige E, Ramond A, Reeves GK, Rolland B, Sacerdote C, Sattar N, Anopoulou ES, Stevens J, Thun M, Ueshima H, Yang L, Duk Yun Y, Willeit P, Banks E, Beral V, Chen Z, Gapstur SM, Gunter MJ, Hartge P, Jee SH, Lam TH, Peto R, Potter JD, Willett WC, Thompson SG, Danesh J, Hu FB. 2016. Bodymass index and all-cause mortality: individual-participant-data meta-analysis of 239 prospective studies in four continents. The Lancet 388:776-786. DOI: 10.1016/S01406736(16)30175-1.

Aune D, Sen A, Prasad M, Norat T, Janszky I, Tonstad S, Romundstad P, Vatten LJ. BMI and all cause mortality: systematic review and non-linear dose-response meta-analysis of 230 cohort studies with 3.74 million deaths among 30.3 million participants. DOI: 10.1136/bmj.i2156.

Berumen J, Orozco L, Betancourt-Cravioto M, Gallardo H, Zulueta M, Mendizabal L, Simon L, Benuto RE, Ramírez-Campos E, Marin M, Juárez E, García-Ortiz H, Martínez-Hernández A, Venegas-Vega C, Peralta-Romero J, Cruz M, Tapia-Conyer R. 2019. Influence of obesity, parental history of diabetes, and genes in type 2 diabetes: A case-control study. Scientific Reports 9:1-15. DOI: 10.1038/s41598-019-39145-x.

Bouhaha R, Choquet H, Meyre D, Kamoun HA, Ennafaa H, Baroudi T, Sassi R, Vaxillaire M, Elgaaied A, Froguel P, Cauchi S. 2010. TCF7L2 is associated with type 2 diabetes in nonobese individuals from Tunisia. Pathologie Biologie 58:426-429. DOI:

10.1016/j.patbio.2009.01.003.

Cauchi S, Choquet H, Gutiérrez-aguilar R, Capel F, Grau K, Proença C, Dina C, Duval A, Balkau B, Marre M, Potoczna N, Langin D, Horber F, Sørensen TIA. 2008a. Effects of TCF7L2 Polymorphisms on Obesity in European Populations. Obesity Journal 16:476-482. DOI: $10.1038 /$ oby.2007.77.

Cauchi S, Meyre D, Dina C, Samson C, Gallina S, Balkau B, Charpentier G, Stetsyuk V, Staels

Peer) reviewing PDF | (2020:10:53366:2:0:NEW 25 Mar 2021) 
523

524

525

526

527

528

529

530

531

532

533

534

535

536

537

538

539

540

541

542

543

544

545

546

547

548

549

550

551

552

553

554

555

556

557

558

559

560

561

562

563

564

565

566

567

568
B, Frühbeck G, Froguel P. 2006. ranscription factor TCF7L2 genetic study in the French population: expression in human beta-cells and adipose tissue and strong association with type 2 diabetes. Diabetes 55:2903-2908. DOI: 10.2337/db06-0474.

Cauchi S, Nead KT, Choquet H, Horber F, Potoczna N, Balkau B, Marre M, Charpentier G, Froguel P, Meyre D. 2008b. The genetic susceptibility to type 2 diabetes may be modulated by obesity status : implications for association studies. BMC Medical Genetics 7903146:19. DOI: $10.1186 / 1471-2350-9-45$.

Chen X, Ayala I, Shannon C, Fourcaudot M, Acharya NK, Jenkinson CP, Heikkinen S, Norton L. 2018. The diabetes gene and wnt pathway effector TCF7L2 regulates adipocyte development and function. Diabetes 67:554-568. DOI: 10.2337/db17-0318.

Chen N, Wang J. 2018. Wnt/ß-Catenin signaling and obesity. Frontiers in Physiology 9:1-15. DOI: $10.3389 /$ fphys.2018.00792.

Corella D, Coltell O, Sorlí J V., Estruch R, Quiles L, Martínez-González MÁ, Salas-Salvadó J, Castañer O, Arós F, Ortega-Calvo M, Serra-Majem L, Gómez-Gracia E, Portolés O, Fiol M, Espino JD, Basora J, Fitó M, Ros E, Ordovás JM. 2016. Polymorphism of the transcription factor 7-like 2 gene (TCF7L2) interacts with obesity on type-2 diabetes in the predimed study emphasizing the heterogeneity of genetic variants in type-2 diabetes risk prediction: Time for obesity-specific genetic risk sc. Nutrients 8. DOI: 10.3390/nu8120793.

Cropano C, Santoro N, Groop L, Dalla Man C, Cobelli C, Galderisi A, Kursawe R, Pierpont B, Goffredo M, Caprio S. 2017. The rs7903146 Variant in the TCF7L2 Gene Increases the Risk of Prediabetes/Type 2 Diabetes in Obese Adolescents by Impairing $\beta$-Cell Function and Hepatic Insulin Sensitivity. Diabetes Care 40:1082-1089. DOI: 10.2337/dc17-0290.

Fernández-Rhodes L, Green Howard A, Graff M, Isasi CR, Highland HM, Young KL, Parra E, Below JE, Qi Q, Kaplan RC, Justice AE, Papanicolaou G, Laurie CC, A Grant SF, Haiman C, F Loos RJ, North KE. 2018. Complex patterns of direct and indirect association between the transcription Factor-7 like 2 gene, body mass index and type 2 diabetes diagnosis in adulthood in the Hispanic Community Health Study/ Study of Latinos. BMC Obesity 5:212. DOI: $10.1186 / \mathrm{s} 40608-018-0200-\mathrm{x}$.

Fisher E, Meidtner K, Ängquist L, Holst C, Hansen RD, Halkjær J, Masala G, Østergaard JN, Overvad K, Palli D, Vimaleswaran KS, Tjønneland A, Van Der A DL, Wareham NJ, Sørensen TIA, Loos RJF, Boeing H. 2012. Influence of dietary protein intake and glycemic index on the association between TCF7L2 HapA and weight gain. American Journal of Clinical Nutrition 95:1468-1476. DOI: 10.3945/ajcn.111.014670.

Gallagher D, Belmonte D, Deurenberg P, Wang Z, Krasnow N, Pi-Sunyer FX, Heymsfield SB. 1998. Organ-tissue mass measurement allows modeling of ree and metabolically active tissue mass. American Journal of Physiology - Endocrinology and Metabolism 275. DOI: 10.1152/ajpendo.1998.275.2.e249.

Ghoch M El, Calugi S, Grave RD. 2018. The Open Nutrition Journal Sarcopenic Obesity: Definition, Health Consequences and Clinical Management. 12:70-73. DOI: $10.2174 / 1874288201812010070$.

Grant SFA. 2019. The TCF7L2 Locus : A Genetic Window Into the Pathogenesis of Type 1 and Type 2 Diabetes. Diabetes Care 42:1624-1629. DOI: 10.2337/dci19-0001.

Grant SFA, Thorleifsson G, Reynisdottir I, Benediktsson R, Manolescu A, Sainz J, Helgason A, Stefansson H, Emilsson V, Helgadottir A, Styrkarsdottir U, Magnusson KP, Walters GB, Palsdottir E, Jonsdottir T, Gudmundsdottir T, Gylfason A, Saemundsdottir J, Wilensky RL, Reilly MP, Rader DJ, Bagger Y, Christiansen C, Gudnason V, Sigurdsson G,

Peer) reviewing PDF | (2020:10:53366:2:0:NEW 25 Mar 2021) 
569

570

571

572

573

574

575

576

577

578

579

580

581

582

583

584

585

586

587

588

589

590

591

592

593

594

595

596

597

598

599

600

601

602

603

604

605

606

607

608

609

610

611

612

613

614

Thorsteinsdottir U, Gulcher JR, Kong A, Stefansson K. 2006. confers risk of type 2 diabetes. 38:320-323. DOI: 10.1038/ng1732.

Haupt A, Thamer C, Heni M, Ketterer C, Machann J, Schick F, Machicao F, Stefan N, Claussen CD, Häring HU, Fritsche A, Staiger H. 2010. Gene variants of TCF7L2 influence weight loss and body composition during lifestyle intervention in a population at risk for type 2 diabetes. Diabetes 59:747-750. DOI: 10.2337/db09-1050.

He T, Zhong PS, Cui Y. 2014. A set-based association test identifies sex-specific gene sets associated with type 2 diabetes. Frontiers in Genetics 5:1-8. DOI: 10.3389/fgene.2014.00395.

Helgason A, Pálsson S, Thorleifsson G, Grant SFA, Emilsson V, Gunnarsdottir S, Adeyemo A, Chen Y, Chen G, Reynisdottir I, Benediktsson R, Hinney A, Hansen T, Andersen G, BorchJohnsen K, Jorgensen T, Schäfer H, Faruque M, Doumatey A, Zhou J, Wilensky RL, Reilly MP, Rader DJ, Bagger Y, Christiansen C, Sigurdsson G, Hebebrand J, Pedersen O, Thorsteinsdottir U, Gulcher JR, Kong A, Rotimi C, Stefánsson K. 2007. Refining the impact of TCF7L2 gene variants on type 2 diabetes and adaptive evolution. Nature Genetics 39:218-225. DOI: 10.1038/ng1960.

Hindy G, Mollet IG, Rukh G, Ericson U, Orho-Melander M. 2016. Several type 2 diabetesassociated variants in genes annotated to WNT signaling interact with dietary fiber in relation to incidence of type 2 diabetes. DOI: 10.1186/s12263-016-0524-4.

Kaminska D, Kuulasmaa T, Venesmaa S, Käkelä P, Vaittinen M, Pulkkinen L, Pääkkönen M, Gylling H, Laakso M, Pihlajamäki J. 2012. Adipose Tissue TCF7L2 Splicing Is Regulated by Weight Loss and Associates With Glucose and Fatty Acid Metabolism. 61:2807-2813. DOI: $10.2337 / \mathrm{db} 12-0239$.

Khadra D, Itani L, Tannir H, Kreidieh D, Masri D El, Ghoch M El. Association between sarcopenic obesity and higher risk of type 2 diabetes in adults: A systematic review and meta-analysis ORCID number: PRISMA 2009 Checklist statement. DOI: 10.4239/wjd.v10.i5.311.

Kim K, Park SM. 2018. Association of muscle mass and fat mass with insulin resistance and the prevalence of metabolic syndrome in Korean adults: a cross-sectional study OPEN. SCientiFiC REPoRtS | 8:2703. DOI: 10.1038/s41598-018-21168-5.

Lebrão ML, Laurenti R. 2005. Saúde, bem-estar e envelhecimento : o estudo SABE no Município de São Paulo. Revista brasileira de epidemiologia = Brazilian journal of epidemiology 8:127-141.

Locke AE, Kahali B, Berndt SI, Justice AE, Pers TH, Day FR, Powell C, Vedantam S, Buchkovich ML, Yang J, Croteau-Chonka DC, Esko T, Fall T, Ferreira T, Gustafsson S, Kutalik Z, Luan J, Mägi R, Randall JC, Winkler TW, Wood AR, Workalemahu T, Faul JD, Smith JA, Zhao JH, Zhao W, Chen J, Fehrmann R, Hedman K, Karjalainen J, Schmidt EM, Absher D, Amin N, Anderson D, Beekman M, Bolton JL, Bragg-Gresham JL, Buyske S, Demirkan A, Deng G, Ehret G, Feenstra B, Feitosa M, Fischer K, Goel A, Gong J, Jackson AU, Kanoni S, Kleber ME, Kristiansson K, Lim U, Lotay V, Mangino M, Leach IM, Medina-Gomez C, Medland SE, Nalls MA, Palmer CD, Pasko D, Pechlivanis S, Peters MJ, Prokopenko I, Shungin D, Stančáková A, Strawbridge RJ, Sung YJ, Tanaka T, Teumer A, Trompet S, van der Laan SW, van Setten J, Van Vliet-Ostaptchouk J V., Wang Z, Yengo L, Zhang W, Isaacs A, Albrecht E, Ärnlöv J, Arscott GM, Attwood AP, Bandinelli S, Barrett A, Bas IN, Bellis C, Bennett AJ, Berne C, Blagieva R, Blüher M, Böhringer S, Bonnycastle LL, Böttcher Y, Boyd HA, Bruinenberg M, Caspersen IH, Chen YI, Clarke R, Daw EW, de

Peer] reviewing PDF | (2020:10:53366:2:0:NEW 25 Mar 2021) 
615

616

617

618

619

620

621

622

623

624

625

626

627

628

629

630

631

632

633

634

635

636

637

638

639

640

641

642

643

644

645

646

647

648

649

650

651

652

653

654

655

656

657

658

659

660

Craen AJM, Delgado G, Dimitriou M, Doney ASF, Eklund N, Estrada K, Eury E, Folkersen L, Fraser RM, Garcia M, Geller F, Giedraitis V, Gigante B, Go AS, Golay A, Goodall A, Gordon SD, Gorski M, Grabe HJ, Grallert H, Grammer TB, Gräßler J, Grönberg H, Groves CJ, Gusto G, Haessler J, Hall P, Haller T, Hallmans G, Hartman CA, Hassinen M, Hayward C, Heard-Costa NL, Helmer Q, Hengstenberg C, Holmen O, Hottenga JJ, James AL, Jeff J, Johansson, Jolley J, Juliusdottir T, Kinnunen L, Koenig W, Koskenvuo M, Kratzer W, Laitinen J, Lamina C, Leander K, Lee NR, Lichtner P, Lind L, Lindström J, Lo KS, Lobbens S, Lorbeer R, Lu Y, Mach F, Magnusson PK, Mahajan A, McArdle WL, McLachlan S, Menni C, Merger S, Mihailov E, Milani L, Moayyeri A, Monda KL, Morken MA, Mulas A, Müller G, Müller-Nurasyid M, Musk AW, Nagaraja R, Nöthen MM, Nolte IM, Pilz S, Rayner NW, Renstrom F, Rettig R, Ried JS, Ripke S, Robertson N, Rose LM, Sanna S, Scharnagl H, Scholtens S, Schumacher F, Scott WR, Seufferlein T, Shi J, Smith A V., Smolonska J, Stanton A V., Steinthorsdottir V, Stirrups K, Stringham HM, Sundström J, Swertz MA, Swift AJ, Syvänen AC, Tan ST, Tayo B, Thorand B, Thorleifsson G, Tyrer J, Uh HW, Vandenput L, Verhulst FC, Vermeulen SH, Verweij N, Vonk JM, Waite LL, Warren HR, Waterworth DM, Weedon MN, Wilkens L, Willenborg C, Wilsgaard T, Wojczynski MK, Wong A, Wright AF, Zhang Q, Brennan EP, Choi M, Dastani Z, Drong AW, Eriksson P, Franco-Cereceda A, Gådin JR, Gharavi AG, Goddard ME, Handsaker RE, Huang J, Karpe F, Kathiresan S, Keildson S, Kiryluk K, Kubo M, Lee JY, Liang L, Lifton RP, Ma B, McCarroll SA, McKnight AJ, Min JL, Moffatt MF, Montgomery GW, Murabito JM, Nicholson G, Nyholt DR, Okada Y, Perry JR, Dorajoo R, Reinmaa E, Salem RM, Sandholm N, Scott RA, Stolk L, Takahashi A, Van't Hooft FM, Vinkhuyzen AAE, Westra HJ, Zheng W, Zondervan KT, Heath AC, Arveiler D, Bakker SJ, Beilby JP, Bergman RN, Blangero J, Bovet P, Campbell H, Caulfield M, Cesana G, Chakravarti A, Chasman D, Chines PS, Collins FS, Crawford D, Cupples L, Cusi D, Danesh J, de Faire U, Den Ruijter HM, Dominiczak AF, Erbel R, Erdmann J, Eriksson JG, Farrall M, Felix SB, Ferrannini E, Ferrières J, Ford I, Forouhi NG, Forrester T, Franco OH, Gansevoort RT, Gejman P V., Gieger C, Gottesman O, Gudnason V, Gyllensten UB, Hall AS, Harris TB, Hattersley AT, Hicks AA, Hindorff L, Hingorani A, Hofman A, Homuth G, Hovingh G, Humphries SE, Hunt SC, Hyppönen E, Illig T, Jacobs KB, Jarvelin MR, Jöckel KH, Johansen B, Jousilahti P, Jukema J, Jula A, Kaprio J, Kastelein JJ, Keinanen-Kiukaanniemi SM, Kiemeney LA, Knekt P, Kooner JS, Kooperberg C, Kovacs P, Kraja AT, Kumari M, Kuusisto J, Lakka T, Langenberg C, Marchand LL, Lehtimäki T, Lyssenko V, Männistö S, Marette A, Matise T, McKenzie CA, McKnight B, Moll FL, Morris AD, Morris AP, Murray JC, Nelis M, Ohlsson C, Oldehinkel AJ, Ong KK, Madden PAF, Pasterkamp G, Peden JF, Peters A, Postma DS, Pramstaller PP, Price JF, Qi L, Raitakari O, Rankinen T, Rao DC, Rice TK, Ridker P, Rioux JD, Ritchie M, Rudan I, Salomaa V, Samani N, Saramies J, Sarzynski MA, Schunkert H, Schwarz PE, Sever P, Shuldiner AR, Sinisalo J, Stolk RP, Strauch K, Tönjes A, Trégouët DA, Tremblay A, Tremoli E, Virtamo J, Vohl MC, Völker U, Waeber G, Willemsen G, Witteman JC, Zillikens MC, Adair LS, Amouyel P, Asselbergs FW, Assimes TL, Bochud M, Boehm BO, Boerwinkle E, Bornstein SR, Bottinger EP, Bouchard C, Cauchi S, Chambers JC, Chanock SJ, Cooper RS, de Bakker PIW, Dedoussis G V., Ferrucci L, Franks PW, Froguel P, Groop L, Haiman C, Hamsten A, Hui J, Hunter DJ, Hveem K, Kaplan RC, Kivimaki M, Kuh D, Laakso M, Liu Y, Martin NG, März W, Melbye M, Metspalu A, Moebus S, Munroe P, Njølstad I, Oostra BA, Palmer CN, Pedersen NL, Perola M, Pérusse L, Peters U, Power C, Quertermous T, Rauramaa R, Rivadeneira F, Saaristo TE,

PeerJ reviewing PDF | (2020:10:53366:2:0:NEW 25 Mar 2021) 
661

662

663

664

665

666

667

668

669

670

671

672

673

674

675

676

677

678

679

680

681

682

683

684

685

686

687

688

689

690

691

692

693

694

695

696

697

698

699

700

701

702

703

704

705

706

Saleheen D, Sattar N, Schadt E, Schlessinger D, Slagboom PE, Snieder H, Spector TD, Thorsteinsdottir U, Stumvoll M, Tuomilehto J, Uitterlinden AG, Uusitupa M, van der Harst P, Walker MC, Wallaschofski H, Wareham N, Watkins H, Weir DR, Wichmann H, Wilson JF, Zanen P, Borecki I, Deloukas P, Fox CS, Heid IM, O'connell JR, Strachan DP, Stefansson K, Van Duijn C, Abecasis G, Franke L, Frayling TM, McCarthy MI, Visscher PM, Scherag A, Willer CJ, Boehnke M, Mohlke KL, Lindgren CM, Beckmann JS, Barroso I, North KE, Ingelsson E, Hirschhorn JN, Loos RJ, Speliotes EK, Thompson JR, Goldstein BA, König IR, Cazier JB, Grundberg E, Havulinna AS, Ho WK, Hopewell JC, Eriksson N, Lundmark P, Lyytikäinen LP, Rafelt S, Tikkanen E, Van Zuydam N, Voight BF, Ziegler A, Altshuler D, Balmforth AJ, Braund PS, Burgdorf C, Claudi-Boehm S, Cox D, Do R, Doney AS, El Mokhtari N, Fontanillas P, Hager J, Han BG, Hunt SE, Kang HM, Kessler T,

Knowles JW, Kolovou G, Langford C, Lokki ML, Lundmark A, Meisinger C, Melander O, Maouche S, Nikus K, Rasheed A, Rosinger S, Rubin D, Rumpf MP, Schäfer A,

Sivananthan M, Song C, Stewart AF, Thorgeirsson G, van der Schoot CE, Wagner PJ, Wells GA, Wild PS, Tsun-Po Y, Basart H, Brambilla P, Cambien F, Cupples AL, Dehghan A, Diemert P, Epstein SE, Evans A, Ferrario MM, Gauguier D, Hazen SL, Holm H, Iribarren C, Jang Y, Kähönen M, Kee F, Kim HS, Klopp N, Kuulasmaa K, Laaksonen R, Ouwehand W, Parish S, Park JE, Rader DJ, Shah S, Stark K, Wallentin L, Zimmermann ME, Nieminen MS, Sandhu MS, Pastinen T, Zalloua PA, Siegbahn A, Schreiber S, Ripatti S, Blankenberg SS, O’donnell C, Reilly MP, Collins R, Roberts R, Pattaro C, Köttgen A, Garnaas M, Böger CA, Fuchsberger C, Olden M, Chen MH, Tin A, Taliun D, Li M, Gao X, Yang Q, Hundertmark C, Foster MC, O'seaghdha CM, Glazer N, Liu CT, Struchalin M, Li G, Johnson AD, Gierman HJ, Hwang SJ, Atkinson EJ, Lohman K, Cornelis MC, Chouraki V, Holliday EG, Sorice R, Deshmukh H, Ulivi S, Chu AY, Murgia F, Imboden M, Kollerits B, Pistis G, Launer L, Aspelund T, Eiriksdottir G, Mitchell BD, Schmidt H, Cavalieri M, Rao M, Hu FB, de Andrade M, Turner ST, Ding J, Andrews JS, Freedman BI, Döring A, Kolcic I, Zemunik T, Boban M, Minelli C, Wheeler HE, Igl W, Zaboli G, Wild SH, Ellinghaus D, Nöthlings U, Jacobs G, Biffar R, Endlich K, Ernst F, Kroemer HK, Nauck M, Stracke S, Völzke H, Aulchenko YS, Polasek O, Hastie N, Vitart V, Helmer C, Wang JJ, Ruggiero D, Bergmann S, Viikari J, Nikopensius T, Province M, Ketkar S, Colhoun H, Doney A, Robino A, Giulianini F, Krämer BK, Portas L, Buckley BM, Adam M, Thun GA, Paulweber B, Haun M, Sala C, Metzger M, Mitchell P, Ciullo M, Kim SK, Vollenweider P, Palmer C, Gasparini P, Pirastu M, Probst-Hensch NM, Kronenberg F, Toniolo D, Coresh J, Schmidt R, Siscovick D, Kardia SL, Curhan GC, Franke A, Parsa A, Goessling W, Kao W, de Boer IH, Peralta CA, Akylbekova E, Kramer H, Arking DE, Franceschini N, Egan J, Hernandez D, Townsend RR, Lumley T, Psaty B, Kestenbaum B, Haritunians T, Mooser V, Florez JC, Meigs JB, Lu X, Leak TS, Aasarød K, Skorpen F, Baumert J, Devuyst O, Mychaleckyj JC, Kedenko L, Coassin S, Hallan S, Navis G, Shlipak MG, Bull SB, Paterson AD, Rotter JI, Dreisbach AW, Anderson CA, Guo Q, Henders A, Lambert A, Lee SH, Kraft P, Kennedy SH, Macgregor S, Missmer SA, Painter JN, Roseman F, Treloar SA, Wallace L, Forsblom C, Isakova T, McKay GJ, Williams WW, Sadlier DM, Mäkinen VP, Swan EJ, Boright AP, Ahlqvist E, Keller BJ, Huang H, Ahola A, Fagerholm E, Gordin D, Harjutsalo V, He B, Heikkilä O, Hietala K, Kytö J, Lahermo P, Lehto M, Österholm AM, Parkkonen M, Pitkäniemi J, Rosengård-Bärlund M, Saraheimo M, Sarti C, Söderlund J, Soro-Paavonen A, Syreeni A, Thorn LM, Tikkanen H, Tolonen N, Tryggvason K, Wadén J, Gill G V., Prior S, Guiducci C, Mirel D, Taylor A, Hosseini M, Parving HH, Rossing P, Tarnow L,

Peer) reviewing PDF | (2020:10:53366:2:0:NEW 25 Mar 2021) 
707

708

709

710

711

712

713

714

715

716

717

718

719

720

721

722

723

724

725

726

727

728

729

730

731

732

733

734

735

736

737

738

739

740

741

742

743

744

745

746

747

748

749

750

751

752
Ladenvall C, Alhenc-Gelas F, Lefebvre P, Rigalleau V, Roussel R, Tregouet DA, Maestroni A, Maestroni S, Falhammar H, Gu T, Möllsten A, Cimponeriu D, Mihai I, Mota M, Mota E, Serafinceanu C, Stavarachi M, Hanson RL, Nelson RG, Kretzler M, Panduru NM, Gu HF, Brismar K, Zerbini G, Hadjadj S, Marre M, Lajer M, Waggott D, Savage DA, Bain SC, Martin F, Godson C, Groop PH, Maxwell AP, Sengupta S, Peloso GM, Ganna A, Mora S, Chang HY, Den Hertog HM, Donnelly LA, Freitag DF, Gurdasani D, Heikkilä K, Johnson T, Kaakinen M, Kettunen J, Li X, Montasser ME, Petersen AK, Saxena R, Service SK, Sidore C, Surakka I, Teslovich TM, Van den Herik EG, Volcik KA, Wu Y, Asiki G, Been LF, Burnett MS, Doring A, Elliott P, Eyjolfsson GI, Goodarzi MO, Gravito ML, Hartikainen AL, Hung YJ, Jones MR, Kaleebu P, Khaw KT, Kim E, Komulainen P, Lehtimaki T, Lin SY, Lindstrom J, Muller G, Narisu N, Nieminen T V., Nsubuga RN, Olafsson I, Palotie A, Papamarkou T, Pomilla C, Pouta A, Ruokonen A, Seeley J, Silander K, Tiret L, van Pelt L, Wainwright N, Wijmenga C, Young EH, Bennett F, Boomsma DI, Burnier M, Chen YD, Feranil AB, Ferrieres J, Freimer NB, Hsiung CA, Kesäniemi A, Koudstaal PJ, Krauss RM, Kyvik KO, Meneton P, Moilanen L, Sanghera DK, Sheu WH, Whitfield JB, Wolffenbuttel BH, Ordovas JM, Rich SS, Johnson A, Johnson L, Larson MG, Levy D, Newton-Cheh C, O'reilly PF, Palmas W, Rice K, Smith A, Snider H, Tobin M, Verwoert G, Rice KM, Verwoert GC, Pihur V, Heath S, Sõber S, Arora P, Zhang F, Lucas G, Milaneschi Y, Parker AN, Fava C, Fox ER, Go MJ, Sjögren M, Vinay D, Alexander M, Tabara Y, Shaw-Hawkins S, Whincup PH, Shi G, Seielstad M, Sim X, Nguyen KD, Matullo G, Gaunt TR, Onland-Moret NC, Cooper MN, Platou CG, Org E, Hardy R, Dahgam S, Palmen J, Kuznetsova T, Uiterwaal CS, Adeyemo A, Ludwig B, Tomaszewski M, Tzoulaki I, Palmer ND, Chang YP, Steinle NI, Grobbee DE, Morrison AC, Najjar S, Hadley D, Brown MJ, Connell JM, Day IN, Lawlor DA, Lawrence RW, Ongen H, Li Y, Young JH, Bis JC, Bolton JA, Chaturvedi N, Islam M, Jafar TH, Kulkarni SR, Howard P, Guarrera S, Ricceri F, Emilsson V, Plump AS, Weder AB, Sun Y V., Scott LJ, Peltonen L, Vartiainen E, Brand SM, Staessen JA, Wang TJ, Burton PR, Artigas MS, Dong Y, Wang X, Zhu H, Rudock ME, Heckbert SR, Smith NL, Wiggins KL, Doumatey A, Shriner D, Veldre G, Viigimaa M, Kinra S, Prabhakaran D, Tripathy V, Langefeld CD, Rosengren A, Thelle DS, Corsi AM, Singleton A, Hilton G, Salako T, Iwai N, Kita Y, Ogihara T, Ohkubo T, Okamura T, Ueshima H, Umemura S, Eyheramendy S, Meitinger T, Cho YS, Kim HL, Scott J, Sehmi JS, Hedblad B, Nilsson P, Smith GD, Raffel LJ, Yao J, Schwartz SM, Ikram M, W L, Mosley TH, Seshadri S, Shrine NR, Wain L V., Zitting P, Cooper JA, van Gilst WH, Janipalli CS, Mani K, Yajnik CS, Mattace-Raso FU, Lakatta EG, Orru M, Scuteri A, Ala-Korpela M, Kangas AJ, Soininen P, Tukiainen T, Würtz P, Ong RT, Dörr M, Galan P, Hercberg S, Lathrop M, Zelenika D, Zhai G, Meschia JF, Sharma P, Terzic J, Kumar M, Denniff M, Zukowska-Szczechowska E, Wagenknecht LE, Fowkes F, Charchar FJ, Guo X, Rotimi C, Bots ML, Brand E, Talmud PJ, Nyberg F, Laan M, Palmer LJ, van der Schouw YT, Casas JP, Vineis P, Ganesh SK, Wong TY, Tai ES, Morris RW, Marmot MG, Miki T, Chandak GR, Zhu X, Elosua R, Soranzo N, Sijbrands EJ, Uda M, Vasan RS, Järvelin MR, Alizadeh BZ, de Boer RA, Boezen HM, Hillege HL, van der Klauw MM, Ormel J, Rosmalen JG, Slaets JP, Lagou V, Welch RP, Wheeler E, Rehnberg E, Rasmussen-Torvik LJ, Lecoeur C, Johnson PC, Sennblad B, Salo P, Timpson NJ, Evans DM, St Pourcain B, Bielak LF, Horikoshi M, Navarro P, Raychaudhuri S, Chen H, Rybin D, Willems SM, Song K, An P, Marullo L, Jansen H, Pankow J, Edkins S, Varga T V., Oksa H, Antonella M, Kong A, Herder C, Antti J, Small KS, Miljkovic I, Atalay M, Kiess W, Smit JH, Campbell 
753

754

755

756

757

758

759

760

761

762

763

764

765

766

767

768

769

770

771

772

773

774

775

776

777

778

779

780

781

782

783

784

785

786

787

788

789

790

791

792

793

794

795

796

797

798

S, Fowkes GR, Rathmann W, Maerz W, Watanabe RM, de Geus EJ, Penninx BW, Toenjes A, Peyser PA, Körner A, Dupuis J, Cucca F, Balkau B, Bouatia-Naji N, Purcell S, Musunuru K, Ardissino D, Mannucci PM, Anand S, Engert JC, Morgan T, Spertus JA, Stoll M, Girelli D, McKeown PP, Patterson CC, Merlini PA, Berzuini C, Bernardinelli L, Peyvandi F, Tubaro M, Celli P, Fetiveau R, Marziliano N, Casari G, Galli M, Ribichini F, Rossi M, Bernardi F, Zonzin P, Piazza A, Yee J, Friedlander Y, Marrugat J, Subirana I, Sala J, Ramos R, Williams G, Nathan DM, Macrae CA, Berglund G, Asselta R, Duga S, Spreafico M, Daly MJ, Nemesh J, Korn JM, Surti A, Gianniny L, Parkin M, Burtt N, Gabriel SB, Wright BJ, Ball SG, Schunkert I, Linsel-Nitschke P, Lieb W, Fischer M, Grosshennig A, Preuss M, Scholz M, Chen Z, Wilensky R, Matthai W, Qasim A, Hakonarson HH, Devaney J, Pichard AD, Kent KM, Satler L, Lindsay JM, Waksman R, Knouff CW, Scheffold T, Berger K, Huge A, Martinelli N, Olivieri O, Corrocher R, Hólm H, Xie C, Ahmadi KR, Ainali C, Bataille V, Bell JT, Buil A, Dermitzakis ET, Dimas AS, Durbin R, Glass D, Hassanali N, Ingle C, Knowles D, Krestyaninova M, Lowe CE, Meduri E, Di Meglio P, Montgomery SB, Nestle FO, Nica AC, Nisbet J, O'rahilly S, Parts L, Potter S, Sekowska M, Shin SY, Surdulescu G, Travers ME, Tsaprouni L, Tsoka S, Wilk A, Yang TP, Higashio J, Williams R, Nato A, Ambite JL, Deelman E, Manolio T, Heiss G, Taylor K, Avery C, Graff M, Lin D, Quibrera M, Cochran B, Kao L, Umans J, Cole S, Maccluer J, Person S, Gross M, Fornage M, Durda P, Jenny N, Patsy B, Arnold AM, Buzkova P, Haines J, Murdock D, Glenn K, Brown-Gentry K, Thornton-Wells T, Dumitrescu L, Bush WS, Mitchell SL, Goodloe R, Wilson S, Boston J, Malinowski J, Restrepo N, Oetjens M, Fowke J, Spencer K, Pendergrass S, Le Marchand L, Park L, Tiirikainen M, Kolonel L, Cheng I, Wang H, Shohet R, Stram D, Henderson B, Monroe K, Anderson G, Carlson C, Prentice R, Lacroix A, Wu C, Carty C, Rosse S, Young A, Kocarnik J, Lin Y, Jackson R, Duggan D, Kuller L, He C, Sulem P, Barbalic M, Broer L, Byrne EM, Gudbjartsson DF, McArdle PF, Porcu E, van Wingerden S, Zhuang W V., Lauc LB, Broekmans FJ, Burri A, Chen C, Corre T, Coviello AD, D'adamo P, Davies G, Deary IJ, Ebrahim S, Fauser BC, Ferreli L, Folsom AR, Hankinson SE, Hass M, Janssens AC, Karasik D, Keyzer J, Kiel DP, Lahti J, Lai S, Laisk T, Laven JS, Liu J, Lopez LM, Louwers Y V., Marongiu M, Klaric IM, Masciullo C, Melzer D, Newman AB, Paré G, Peeters PH, Pop VJ, Räikkönen K, Salumets A, Stacey SN, Starr JM, Stathopoulou MG, Styrkarsdottir U, Tenesa A, Tryggvadottir L, Tsui K, van Dam RM, van Gils CH, van Nierop P, Vink JM, Voorhuis M, Widen E, Wijnands-Van Gent CJ, Yerges-Armstrong LM, Zgaga L, Zygmunt M, Buring JE, Crisponi L, Demerath EW, Streeten EA, Murray A, Visser JA, Lunetta KL, Elks CE, Cousminer DL, Koller DL, Lin P, Smith EN, Warrington NM, Alavere H, Berenson GS, Blackburn H, Busonero F, Chen W, Couper D, Easton DF, Eriksson J, Foroud T, Kilpeläinen TO, Li S, Murray SS, Ness AR, Northstone K, Peacock M, Pennell CE, Pharoah P, Rafnar T, Rice JP, Ring SM, Schork NJ, Segrè A V., Sovio U, Srinivasan SR, Tammesoo ML, van Meurs JB, Young L, Bierut LJ, Econs MJ. 2015. Genetic studies of body mass index yield new insights for obesity biology. Nature 518:197-206. DOI: 10.1038/nature14177.

Lyssenko V, Lupi R, Marchetti P, Guerra S Del, Orho-melander M, Almgren P, Sjögren M, Ling C, Eriksson K, Lethagen Å, Mancarella R, Berglund G, Tuomi T, Nilsson P, Prato S Del, Groop L. 2007. Mechanisms by which common variants in the TCF7L2 gene increase risk of type 2 diabetes. 117:2155-2163. DOI: 10.1172/JCI30706DS1.

Mattei J, Qi Q, Hu FB, Sacks FM, Qi L. 2012. TCF7L2 genetic variants modulate the effect of dietary fat intake on changes in body composition during a weight-loss intervention.

Peer) reviewing PDF | (2020:10:53366:2:0:NEW 25 Mar 2021) 
808

809

810

811

812

813

814

815

816

817

818

819

820

821

822

823

824

825

826

827

828

829

830

831

832

833

834

835

836

837

838

839

840

841

842

843

844

American Journal of Clinical Nutrition 96:1129-1136. DOI: 10.3945/ajcn.112.038125.

Mondal AK, Das SK, Baldini G, Chu WS, Sharma NK, Hackney OG, Zhao J, Grant SFA, Elbein SC. 2010. Genotype and tissue-specific effects on alternative splicing of the transcription factor 7-like 2 gene in humans. Journal of Clinical Endocrinology and Metabolism 95:1450-1457. DOI: 10.1210/jc.2009-2064.

Muller YL, Hanson RL, Piaggi P, Chen P, Wiessner G, Okani C, Skelton G, Kobes S, Hsueh W, Knowler WC, Bogardus C, Baier LJ. 2019. Assessing the Role of 98 Established Loci for Body Mass Index in American Indians. Obesity 27:845-854. DOI: 10.1002/oby.22433.Assessing.

Naslavsky MS, Scliar MO, Yamamoto GL, Wang JYT, Zverinova S, Karp T, Nunes K, Ceroni JRM, de Carvalho DL, da Silva Simões CE, Bozoklian D, Nonaka R, Silva N dos SB, da Silva Souza A, de Souza Andrade H, Passos MRS, Castro CFB, Mendes-Junior CT, Mercuri RL V, Miller TLA, Buzzo JL, Rego FO, Araújo NM, Magalhães WCS, Célia Mingroni-Netto R, Borda V, Guio H, Barreto ML, Lima-Costa MF, Horta BL, TarazonaSantos E, Meyer D, Galante PAF, Guryev V, Castelli EC, Duarte YAO, Passos-Bueno MR, Zatz M. 2020. Whole-genome sequencing of 1,171 elderly admixed individuals from the largest Latin American metropolis (São Paulo, Brazil). bioRxiv:2020.09.15.298026. DOI: 10.1101/2020.09.15.298026.

Naslavsky MS, Yamamoto GL, de Almeida TF, Ezquina SAM, Sunaga DY, Pho N, Bozoklian D, Sandberg TOM, Brito LA, Lazar M, Bernardo DV, Amaro E, Duarte YAO, Lebrão ML, Passos-Bueno MR, Zatz M. 2017. Exomic variants of an elderly cohort of Brazilians in the ABraOM database. Human Mutation 38:751-763. DOI: 10.1002/humu.23220.

Nilsson E, Jansson PA, Perfilyev A, Volkov P, Pedersen M, Svensson MK, Poulsen P, RibelMadsen R, Pedersen NL, Almgren P, Fadista J, Rönn T, Pedersen BK, Scheele C, Vaag A, Ling C. 2014. Altered DNA methylation and differential expression of genes influencing metabolism and inflammation in adipose tissue from subjects with type 2 diabetes. Diabetes 63:2962-2976. DOI: 10.2337/db13-1459.

Noordam R, Zwetsloot CPA, de Mutsert R, Mook-Kanamori DO, Lamb HJ, de Roos A, de Koning EJP, Rosendaal FR, Willems van Dijk K, van Heemst D. 2017. Interrelationship of the rs7903146 TCF7L2 gene variant with measures of glucose metabolism and adiposity: The NEO study. Nutrition, Metabolism and Cardiovascular Diseases 31:150-157. DOI: 10.1016/j.numecd.2017.10.012.

Ouhaibi-Djellouli H, Mediene-Benchekor S, Lardjam-Hetraf SA, Hamani-Medjaoui I, Meroufel DN, Boulenouar H, Hermant X, Saidi-Mehtar N, Amouyel P, Houti L, Goumidi L, Meirhaeghe A. 2014. The TCF7L2 rs7903146 polymorphism, dietary intakes and type 2 diabetes risk in an Algerian population. DOI: 10.1186/s12863-014-0134-3.

Pang DX, Smith AJP, Humphries SE. 2013. Functional analysis of TCF7L2 genetic variants associated with type 2 diabetes. Nutrition, Metabolism and Cardiovascular Diseases 23:550-556. DOI: 10.1016/j.numecd.2011.12.012.

Perry JRB, Voight BF, Yengo L, Amin N, Dupuis J, Ganser M, Grallert H, Navarro P, Li M, Qi L, Steinthorsdottir V, Scott RA, Almgren P, Arking DE, Aulchenko Y, Balkau B, Benediktsson R, Bergman RN, Boerwinkle E, Bonnycastle L, Burtt NP, Campbell H, Charpentier G, Collins FS, Gieger C, Green T, Hadjadj S, Hattersley AT, Herder C, Hofman A, Johnson AD, Kottgen A, Kraft P, Labrune Y, Langenberg C, Manning AK, Mohlke KL, Morris AP, Oostra B, Pankow J, Petersen AK, Pramstaller PP, Prokopenko I, Rathmann W, Rayner W, Roden M, Rudan I, Rybin D, Scott LJ, Sigurdsson G, Sladek R, 
845

846

847

848

849

850

851

852

853

854

855

856

857

858

859

860

861

862

863

864

865

866

867

868

869

870

871

872

873

874

875

876

877

878

879

880

881

882

883

884

885

886

887

Thorleifsson G, Thorsteinsdottir U, Tuomilehto J, Uitterlinden AG, Vivequin S, Weedon MN, Wright AF, Hu FB, Illig T, Kao L, Meigs JB, Wilson JF, Stefansson K, van Duijn C, Altschuler D, Morris AD, Boehnke M, McCarthy MI, Froguel P, Palmer CNA, Wareham NJ, Groop L, Frayling TM, Cauchi S. 2012. Stratifying type 2 diabetes cases by BMI identifies genetic risk variants in LAMA1 and enrichment for risk variants in lean compared to obese cases. PLoS Genetics 8. DOI: 10.1371/journal.pgen.1002741.

Ponti F, Santoro A, Mercatelli D, Gasperini C, Conte M, Martucci M, Sangiorgi L, Franceschi C, Bazzocchi A. 2020. Aging and Imaging Assessment of Body Composition: From Fat to Facts. Frontiers in Endocrinology 10. DOI: 10.3389/fendo.2019.00861.

Ross SE, Hemati N, Longo KA, Bennett CN, Lucas PC, Erickson RL, MacDougald OA. 2000. Inhibition of adipogenesis by Wnt signaling. Science 289:950-953. DOI:

10.1126/science.289.5481.950.

Roswall N, Ängquist L, Ahluwalia TS, Romaguera D, Larsen SC, Østergaard JN, Halkjær J, Vimaleswaran KS, Wareham NJ, Bendinelli B, Palli D, Boer JMA, Van Der A DL, Boeing H, Loos RJF, Sørensen TIA, Tjønneland A. 2014. Association between Mediterranean and Nordic diet scores and changes in weight and waist circumference: Influence of FTO and TCF7L2 loci. American Journal of Clinical Nutrition 100:1188-1197. DOI: 10.3945/ajcn.114.089706.

Sayer AA, Syddall H, Martin H, Patel H, Baylis D, Cooper C. 2008. The developmental origins of sarcopenia. Journal of Nutrition, Health and Aging 12:427. DOI: 10.1007/BF02982703.

Stolerman ES, Manning AK, McAteer JB, Fox CS, Dupuis J, Meigs JB, Florez JC. 2009. TCF7L2 variants are associated with increased proinsulin/insulin ratios but not obesity traits in the Framingham Heart Study. Diabetologia 52:614-620. DOI: 10.1007/s00125-0091266-2.

Vaquero AR, Ferreira NE, Omae S V, Rodrigues M V, Teixeira SK, Krieger JE, Pereira AC. 2012. Using gene-network landscape to dissect genotype effects of TCF7L2 genetic variant on diabetes and cardiovascular risk. Physiological genomics 44:903-14. DOI: 10.1152/physiolgenomics.00030.2012.

Watanabe RM, Allayee H, Xiang AH, Trigo E, Hartiala J, Lawrence JM, Buchanan T a. 2007. With Gestational Diabetes Mellitus and Interacts With Adiposity to Alter Insulin Secretion in Mexican Americans. Diabetes 56:1481-1485. DOI: 10.2337/db06-1682.Additional.

Zhou Y, Oskolkov N, Shcherbina L, Ratti J, Kock KH, Su J, Martin B, Oskolkova MZ, Göransson O, Bacon J, Li W, Bucciarelli S, Cilio C, Brazma A, Thatcher B, Rung J, Wierup N, Renström E, Groop L, Hansson O. 2016. HMGB1 binds to the rs7903146 locus in TCF7L2 in human pancreatic islets. Molecular and Cellular Endocrinology 430:138-145. DOI: 10.1016/j.mce.2016.01.027.

Zhou Y, Park S, Su J, Bailey K, Ottosson-laakso E, Shcherbina L, Oskolkov N, Zhang E, Thevenin T, Bennet H, Vikman P, Wierup N, Fex M, Rung J, Wollheim C, Groop L, Hansson O, Nobrega M, Renstro E. 2014. TCF7L2 is a master regulator of insulin production and processing. Human Molecular Genetics 23:6419-6431. DOI: $10.1093 / \mathrm{hmg} / \mathrm{ddu} 359$.

Peer) reviewing PDF | (2020:10:53366:2:0:NEW 25 Mar 2021) 


\section{Table $\mathbf{1}$ (on next page)}

Anthropometric and biochemical characteristics according to Body Mass Index status.

Data are presented as median and range for the most variables; P-value with Kruskal-Wallis test for quantitative variables and Chi-square test for qualitative data. BMI classification criteria: normal-weight $\left(18.5-24.9 \mathrm{~kg} / \mathrm{m}^{2}\right)$, overweight $\left(25.0-29.9 \mathrm{~kg} / \mathrm{m}^{2}\right)$, obesity $(\geq 30.0$ $\mathrm{kg} / \mathrm{m}^{2}$ ). P, P-value; T2DM, Type 2 diabetes mellitus; M/F, Male/Female; BMI, Body mass index; LDL, low density lipoprotein; HDL, high density lipoprotein. 
Table 12

Anthropometric and biochemical characteristics according to Body Mass Index status.

\begin{tabular}{lllllc}
\hline Variable & Unit & Normal-weight & Overweight & Obesity & P \\
\hline Population size & $\mathrm{N}$ & 280 & 424 & 319 & - \\
Gender M/F & $\mathrm{N} / \mathrm{N}$ & $115 / 165$ & $183 / 241$ & $67 / 252$ & $<0.0001$ \\
Age & years old & $74.3(65.8-82.6)$ & $71.6(64.5-79.2)$ & $67.9(64.0-75.2)$ & $<0.0001$ \\
BMI & $\mathrm{kg} / \mathrm{m}^{2}$ & $22.8(21.0-24.0)$ & $27.3(26.2-28.4)$ & $33.1(31.2-35.9)$ & $<0.0001$ \\
Waist circumference & $\mathrm{cm}$ & $82.0(77.8-87.0)$ & $94.0(89.0-99.0)$ & $105.0(100.0-110.0)$ & $<0.0001$ \\
Hip circumference & $\mathrm{cm}$ & $93.0(90.0-96.0)$ & $101.0(98.0-104.0)$ & $113.0(108.0-120.0)$ & $<0.0001$ \\
Hip-waist ratio & $\mathrm{cm} / \mathrm{cm}$ & $0.88(0.83-0.93)$ & $0.93(0.88-0.98)$ & $0.91(0.87-0.97)$ & $<0.0001$ \\
Systolic pressure & $\mathrm{mmHg}$ & $134.3(121.7-152.0)$ & $138.0(127.7-153.0)$ & $138.0(125.0-155.0)$ & 0.0664 \\
Diastolic pressure & $\mathrm{mmHg}$ & $76.2(68.3-85.8)$ & $79.7(72.0-86.3)$ & $81.0(74.2-90.0)$ & $<0.0001$ \\
Plasma glucose & $\mathrm{mg} / \mathrm{dL}$ & $85.0(78.0-95.0)$ & $88.0(81.0-102.3)$ & $93.0(84.0-107.0)$ & $<0.0001$ \\
Glycated hemoglobin & $\%$ & $5.7(5.5-6.0)$ & $5.8(5.6-6.1)$ & $5.9(5.6-6.3)$ & $<0.0001$ \\
Total cholesterol & $\mathrm{mg} / \mathrm{dL}$ & $202.5(177.0-234.5)$ & $200.0(176.0-228.0)$ & $207.0(180.0-230.5)$ & 0.3732 \\
Fasting triglyceride & $\mathrm{mg} / \mathrm{dL}$ & $102.5(75.0-137.3)$ & $116.5(89.8-167.3)$ & $126.0(94.0-168.5)$ & $<0.0001$ \\
LDL cholesterol & $\mathrm{mg} / \mathrm{dL}$ & $126.0(104.0-148.0)$ & $124.0(104.8-149.0)$ & $130.0(106.5-151.0)$ & 0.7908 \\
HDL cholesterol & $\mathrm{mg} / \mathrm{dL}$ & $52.0(42.8-62.0)$ & $45.0(38.0-54.0)$ & $47.0(41.0-56.0)$ & $<0.0001$ \\
T2DM & $\mathrm{N}(\%)$ & $51(18)$ & $117(28)$ & $92(29)$ & 0.0048 \\
Hypertensive & $\mathrm{N}(\%)$ & $166(59)$ & $279(66)$ & $254(80)$ & $<0.0001$ \\
\hline
\end{tabular}

Data are\&resented as median and range for the most variables; P-value with Kruskal-Wallis test for quantitative variables and Chi-square test for qualitatibe data.

BMI cla6sification criteria: normal-weight $\left(18.5-24.9 \mathrm{~kg} / \mathrm{m}^{2}\right)$, overweight $\left(25.0-29.9 \mathrm{~kg} / \mathrm{m}^{2}\right)$, obesity $\left(\geq 30.0 \mathrm{~kg} / \mathrm{m}^{2}\right)$.

P, P-value; T2DM, Type 2 diabetes mellitus; M/F, Male/Female; BMI, Body mass index; LDL, low density lipoprotein; HDL, high density lipoprotein.

8
9
10
11
12
13
14
15
16
17
18
19
20
21
22
23
24
25
26
27
28
29
30
31
32
33
34




\section{Table 2(on next page)}

Association between rs7903146 TT genotype and risk for Type 2 diabetes adjusted for the confounding variables.

Regression logistic analysis was adopted. 
1

Table 2. Association between rs7903146 TT genotype and risk for Type 2 diabetes adjusted for the 2 confounding variables.

\begin{tabular}{lccc}
\hline Possible confounding variable & $P$-value & Odds Ratio & 95\% Confidence Interval \\
\hline Age (years old) & 0.005 & 1.89 & $1.21-2.95$ \\
Gender (N) & 0.005 & 1.90 & $1.22-2.97$ \\
BMI $\left(\mathrm{kg} / \mathrm{m}^{2}\right)$ & 0.003 & 1.95 & $1.25-3.06$ \\
Waist circumference (cm) & 0.004 & 1.93 & $1.23-3.02$ \\
Diastolic pressure $(\mathrm{mmHg})$ & 0.006 & 1.88 & $1.20-2.93$ \\
Glycated hemoglobina (\%) & 0.004 & 2.34 & $1.31-4.18$ \\
Fasting triglyceride (mg/dL) & 0.005 & 1.90 & $1.22-2.97$ \\
HDL cholesterol (mg/dL) & 0.006 & 1.87 & $1.19-2.92$ \\
European ancestrie $(\%)$ & 0.005 & 1.92 & $1.21-3.05$ \\
All confounders toghether & 0.006 & 2.35 & $1.28-4.32$
\end{tabular}

Regression logistic analysis was adopted. 


\section{Table 3 (on next page)}

Association of the rs7903146 T allele with type 2 diabetes mellitus according to Body Mass Index status.

Volunteers without type 2 diabetes mellitus were considered as the control group.

BMI classification criteria: normal-weight $\left(18.5-24.9 \mathrm{~kg} / \mathrm{m}^{2}\right)$, overweight $\left(25.0-29.9 \mathrm{~kg} / \mathrm{m}^{2}\right)$, obesity $(\geq 30.0$ $\left.\mathrm{kg} / \mathrm{m}^{2}\right)$. P, P-value; $95 \% \mathrm{Cl}, 95 \%$ confidence interval; OR, odds ratio OR adjusted for sex and age. 
Table 3

Association of the rs $7903146 \mathrm{~T}$ allele with type 2 diabetes mellitus according to Body Mass Index status.

Volunteers without type 2 diabetes mellitus were considered as the control group.

BMI classification criteria: normal-weight $\left(18.5-24.9 \mathrm{~kg} / \mathrm{m}^{2}\right)$, overweight $\left(25.0-29.9 \mathrm{~kg} / \mathrm{m}^{2}\right)$, obesity $\left(\geq 30.0 \mathrm{~kg} / \mathrm{m}^{2}\right)$.

\begin{tabular}{|c|c|c|c|c|c|c|c|c|c|}
\hline \multirow{2}{*}{ BMI Status } & \multirow{2}{*}{$\mathrm{N}$} & \multicolumn{2}{|c|}{$\begin{array}{l}\text { Dominant model } \\
(\mathrm{CC} \text { Vs CT+TT })\end{array}$} & \multicolumn{2}{|c|}{$\begin{array}{l}\text { Recessive Model } \\
\text { (CC+CT Vs TT })\end{array}$} & \multicolumn{2}{|c|}{$\begin{array}{c}\text { Additive Model } \\
(\text { CC Vs TT })\end{array}$} & \multicolumn{2}{|c|}{$\begin{array}{l}\text { Allelic Model } \\
(\mathrm{C} \text { Vs T) }\end{array}$} \\
\hline & & OR $(95 \% \mathrm{CI})$ & $\mathrm{P}$ & OR $(95 \% \mathrm{CI})$ & $\mathrm{P}$ & OR $(95 \% \mathrm{CI})$ & $\mathrm{P}$ & OR $(95 \% \mathrm{CI})$ & $\mathrm{P}$ \\
\hline Normal weight & 280 & $1.23(0.66-2.27)$ & 0.512 & $3.36(1.46-7.74)$ & 0.004 & $3.21(1.31-7.87)$ & 0.011 & $1.52(0.97-2.36)$ & 0.066 \\
\hline Overweight & 424 & $1.20(0.78-1.86)$ & 0.401 & $1.96(0.99-3.87)$ & 0.054 & $1.98(0.96-4.10)$ & 0.065 & $1.27(0.92-1.74)$ & 0.141 \\
\hline Obesity & 319 & $1.15(0.71-1.88)$ & 0.565 & $1.23(0.51-2.98)$ & 0.642 & $1.31(0.53-3.28)$ & 0.560 & $1.13(0.78-1.66)$ & 0.516 \\
\hline Normal weight + overweight & 704 & $1.22(0.86-1.73)$ & 0.276 & $2.31(1.37-3.90)$ & 0.002 & $2.34(1.34-4.08)$ & 0.003 & $1.34(1.04-1.73)$ & 0.025 \\
\hline Overweight + obesity & 743 & $1.16(0.84-1.60)$ & 0.370 & $1.59(0.93-2.72)$ & 0.089 & $1.65(0.94-2.89)$ & 0.082 & $1.19(0.94-1.52)$ & 0.155 \\
\hline Total & 1023 & $1.16(0.87-1.54)$ & 0.305 & $1.90(1.22-2.97)$ & 0.005 & $1.94(1.21-3.10)$ & 0.006 & $1.25(1.01-1.54)$ & 0.042 \\
\hline
\end{tabular}

P, P-value; 95\% CI, 95\% confidence interval; OR, odds ratio OR adjusted for sex and age. 


\section{Table 4 (on next page)}

Association of the rs7903146 C allele with the Body Mass Index Status

$\mathrm{P}, \mathrm{P}$-value; $95 \% \mathrm{Cl}, 95 \%$ confidence interval; OR, odds ratio OR adjusted for sex and age. $\mathrm{BMI}$ classification criteria: normal-weight (18.5-24.9 kg/m²), overweight $\left(25.0-29.9 \mathrm{~kg} / \mathrm{m}^{2}\right)$, obesity $\left(\geq 30.0 \mathrm{~kg} / \mathrm{m}^{2}\right)$. 
1 Table 4

2 Association of the rs $7903146 \mathrm{C}$ allele with the Body Mass Index Status

\begin{tabular}{|c|c|c|c|c|c|c|c|c|c|}
\hline \multirow{2}{*}{ Control group } & \multirow{2}{*}{ Case group } & \multicolumn{2}{|c|}{$\begin{array}{c}\text { Dominant model } \\
\text { (TT Vs } \mathrm{CC}+\mathrm{CT} \text { ) }\end{array}$} & \multicolumn{2}{|c|}{$\begin{array}{c}\text { Recessive Model } \\
\text { (TT+CT Vs CC) }\end{array}$} & \multicolumn{2}{|c|}{$\begin{array}{l}\text { Additive Model } \\
\text { (TT Vs CC) }\end{array}$} & \multicolumn{2}{|c|}{$\begin{array}{l}\text { Allelic Model } \\
\text { (T Vs C) }\end{array}$} \\
\hline & & OR $(95 \% \mathrm{CI})$ & $\mathrm{P}$ & OR $(95 \% \mathrm{CI})$ & $\mathrm{P}$ & OR $(95 \% \mathrm{CI})$ & $\mathrm{P}$ & OR $(95 \% \mathrm{CI})$ & $\mathrm{P}$ \\
\hline Normal-weight & Overweight & $1.24(0.74-2.09)$ & 0.410 & $0.92(0.68-1.26)$ & 0.611 & $1.15(0.67-1.98)$ & 0.615 & $1.00(0.79-1.26)$ & 0.984 \\
\hline Normal-weight & Obesity & $1.60(0.88-2.92)$ & 0.122 & $1.41(1.00-1.98)$ & 0.052 & $1.73(0.93-3.21)$ & 0.081 & $1.34(1.03-1.75)$ & 0.029 \\
\hline Normal-weight & Obesity + overweight & $1.32(0.82-2.13)$ & 0.253 & $1.08(0.81-1.43)$ & 0.604 & $1.31(0.80-2.15)$ & 0.286 & $1.10(0.89-1.36)$ & 0.373 \\
\hline Normal-weight + overweight & Obesity & $1.29(0.78-2.11)$ & 0.317 & $1.40(1.06-1.84)$ & 0.017 & $1.48(0.89-2.47)$ & 0.132 & $1.28(1.03-1.58)$ & 0.024 \\
\hline
\end{tabular}

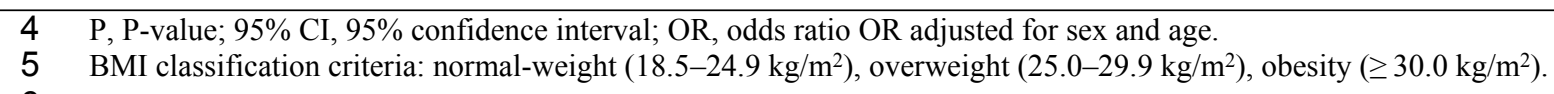




\section{Table 5 (on next page)}

Association between rs7903146 CC genotype and risk for obesity adjusted for the confounding variables.

Regression logistic analysis was adopted. *Association between rs7903146 CC genotype and obesity adjusted by fasting triglyceride: $P=0.034 ; O R=1.0016 ; 95 \%$ Confidence Interval = $1.0001-1.0031$. 
Table 5. Association between rs7903146 CC genotype and risk for obesity adjusted for the confounding variables.

\begin{tabular}{lccc}
\hline Possible confounding variable & $P$-value & Odds Ratio & 95\% Confidence Interval \\
\hline Age (years old) & $<0.001$ & 0.96 & $0.95-0.98$ \\
Gender (N) & $<0.001$ & 2.85 & $2.08-3.89$ \\
Diastolic pressure (mmHg) & $<0.001$ & 1.02 & $1.01-1.03$ \\
Glycated hemoglobina (\%) & 0.032 & 1.13 & $1.01-1.27$ \\
Fasting triglyceride* (mg/dL) & 0.034 & 1.00 & $1.00-1.00$ \\
HDL cholesterol (mg/dL) & 0.443 & 1.00 & $0.99-1.00$ \\
All confounders toghether & 0.017 & 1.41 & $1.06-1.86$
\end{tabular}

Regression logistic analysis was adopted.

*Association between rs7903146 CC genotype and obesity adjusted by fasting triglyceride: $P=0.034$;

$\mathrm{OR}=1.0016 ; 95 \%$ Confidence Interval $=1.0001-1.0031$.

1

2

3 